\title{
Subspecies of Hypolepis rugosula (Dennstaedtiaceae; Pteridophyta) around the world: morphological and biogeographic perspectives
}

Pedro Bond Schwartsburd ${ }^{1,3}$ and Jefferson Prado ${ }^{2}$

Received: 20 February, 2013. Accepted: 5 November, 2013

\begin{abstract}
The "Hypolepis rugosula complex" has been the subject of great debate among pteridologists: some have considered H. rugosula a single subcosmopolitan (or circum-Antarctic) species, whereas others have considered it a species-complex, encompassing several species. In the 1920s and 1930s, four geographically distinct varieties of H. rugosula were recognized. In this work, we present a new taxonomy (with new combinations and statuses, as well as typification and full synonymy), together with complete distribution data for the species, with an infraspecific classification based on morphological and biogeographic perspectives. Hypolepis rugosula occurs in southern temperate regions and high-elevation tropical regions of the Americas, Africa (including Madagascar), Oceania and the Philippines, as well as in some isolated oceanic volcanic islands (e.g., Saint Helena and Tristan da Cunha). Here, 15 geographically distinct subspecies are recognized. All subspecies are geographically segregated from each other, except in New Zealand, where two occur sympatrically-possibly due to two different arrival and colonization times. Four patterns of "indument" (referring to catenate and glandular hairs collectively) are distinguished. Different lineages are successful in their respective habitats; we observed two lineages with different ploidy levels (tetraploid and octoploid). Although long-distance dispersal is the best explanation for the extant distribution of H. rugosula; we do not exclude vicariance as a possible explanation for their occurrence on the land masses that were once united as Gondwana. Therefore, we are assuming that a fern species could remain unchanged for more than $70 \mathrm{Myr}$, and we are adopting the refugia theory, albeit with a different focus.
\end{abstract}

Key words: Cold refugia, Phegopteris rugosula, Polypodium rugosulum, taxonomic revision, widely distributed ferns

\section{Introduction}

Hypolepis rugosula (Labill.) J. Sm. was originally described as Polypodium rugosulum by Labillardière (1806), based on a plant collected in van Diemen's Land (now Tasmania) during the Voyage à la Recherche de la La Pérouse (La Pérouse's Research Expedition), made between 1791 and 1793 (Labillardière 1800, 1802, 1806; Stafleu \& Cowan 1979; Brownsey \& Chinnock 1984, 1987; Schwartsburd \& Prado 2011).

Kaulfuss (1824) attributed the concept of cosmopolitanism (or at least circum-Antarctic distribution) to this species, also identifying plants from Chile as Polypodium rugosulum Labill. He was then seconded by Hooker \& Arnott (1841), Gay (1853), and Brackenridge (1854). Brackenridge (1854: 18) also stated, “... we had some doubts at first, as to the identity of our New Zealand plant with the one from Chili [sic]; but a careful comparison has convinced us that they are one and the same species..." This concept was subsequently complemented by other authors, who gradually increased the knowledge of the range of Polypodium rugosulum (= Hypolepis rugosula): Moore (1857) included several names under the synonymy of Pol. rugosulum; Hooker (1862) considered it subcosmopolitan, recording it from Tasmania, Australia, New Zealand, Norfolk Island, India, Java, China, Ceylon, Chile, Ecuador, Peru and the Juan Fernandez Islands, as well as from the islands of Norfolk, Santa Helena, Tristan da Cunha, Bourbon (Réunion) and Fernando Po (Bioko); Mettenius (1858; 1865-as Phegopteris rugosula (Labill.) Fée) also recorded it from Ostindien ("East Indies"-i.e., Southeast Asia); Cordemoy (1891) recorded it for Réunion Island; Dobbie \& Crookes (1951) recorded and described it in detail from New Zealand, as well as from South Africa and Japan; Brade (1956-then as Hypolepis rugosula) recorded it from the highlands of southeastern Brazil; Tardieu-Blot (1958-as H. villoso-viscida (Thouars) Tardieu) recorded it from the highlands of Belgian Congo; and Tryon \& Tryon (1982-again as H. rugosula) recorded it from "the Americas". Consequently, the name H. rugosula has been adopted by others (Cronk 1989; Agnew \& Agnew

\footnotetext{
${ }^{1}$ Universidade Federal de Viçosa, Departamento de Biologia Vegetal, Viçosa, MG, Brazil

${ }^{2}$ Instituto de Botânica, Herbário SP, São Paulo, SP, Brazil

${ }_{3}^{3}$ Author for correspondence: pedro.schw@ufv.br
} 
1994; Velayos et al. 2008; Schwartsburd 2010). Expressing a different point of view, other authors have considered $P$. rugosulum a species-complex. Such authors have considered P. rugosulum sensu stricto restricted to Australia and Tasmania and have named/described several other similar species from elsewhere: Petit-Thouars $(1808 ; 1811)$ and Carmichael (1818) for Tristan da Cunha; Roxburgh (1816) for Saint Helena (although also recording $P$. rugosulum there); Kunze $(1837 ; 1848 ; 1850)$ for Saint Helena, the Philippines, and Australia; Fée $(1852 ; 1854-1857)$ for Saint Helena and Chile; Jenman $(1881$; 1892) for Jamaica; Philippi (1881) for Chile (although also recording P. rugosula there); Colenso (1883 [1884]) for New Zealand; Hicken (1906) for Argentina; Underwood \& Maxon (1930) for Jamaica; Reimers (1934) for Madagascar and western Africa; Copeland (1942) for New Guinea; Wakefield (1955; 1956), Rawlings (1974), Brownsey \& Chinnock (1984; 1987), and Brownsey et al. (1985) for Australia and New Zealand; Brownsey (1987) for southeastern Asia; Proctor (1985) for Jamaica; Meurk et al. (1994) for Campbell Island; Moran (1995) for Costa Rica; Verdcourt (2000) for the highlands of tropical east Africa; Roux $(2001 ; 2009)$ for South Africa and Madagascar; Mickel \& Smith (2004) for Mexico; Autrey et al. (2008) for the Mascareignes Islands; and Ponce et al. (2008) for Argentina and Chile. However, except for Brownsey \& Chinnock (1984; 1987), few authors have drawn comparisons between the specimens studied and P. rugosulum sensu stricto. A third point of view, even "lumpier" than the first, is that of Hooker \& Baker (1868), Bentham \& Mueller (1878), Hillebrand (1888), Diels (1902? [not explicit]), Christensen (1906), van Alderwerelt van Rosenburgh (1908), Domin (1915), Cheeseman (1925), and Clifton (1997-with uncertainties), who have included Polypodium rugosulum under $P$. punctatum Thunb. (= Hypolepis punctata (Thunb.) Mett.; type from Japan), as a synonym, variety, or subspecies, considering it to be even more widely distributed.

The balanced concept was reached by Christensen and Skottsberg (Christensen 1920, 1931 [1932], 1932, 1934, 1937, 1940; Skottsberg 1920-1956, 1935; Christensen \& Skottsberg 1920) who considered Hypolepis rugosula a circum-Antarctic species, recognizing four geographically distinct varieties: H. rugosula "var. typica" C. Chr., for Australia; H. rugosula var. poeppigii (Kunze) C. Chr., for Chile (including the Juan Fernandez Islands); H. rugosula var. villoso-viscida (Thouars) C. Chr., for Tristan da Cunha; and H. rugosula var. africana C. Chr., for Madagascar. Christensen \& Skottsberg's balanced concept was then adopted by others, such as Alston (1959), Pizarro (1959), Schelpe (1970), Kornaīs (1979), Groves (1981), and Pichi-Sermolli (1983). Schwartsburd \& Prado (2011) and Schwartsburd (2012a; 2012b) recently adopted Christensen \& Skottsberg's concept. However, rather than using the varietal rank, those authors employed the subspecific rank, given that, at the macro level, the populations are virtually segregated and isolated from each other. They named Hypolepis rugosula subsp. pradoana Schwartsb. for the highlands of southern/southeastern Brazil; H. rugosula subsp. poeppigiana (Mett.) Schwartsb. \& J. Prado ined. for Argentina and Chile (including the Juan Fernandez Islands); H. rugosula subsp. africana (C. Chr.) Schwartsb. \& J. Prado for Madagascar and Réunion Island; H. rugosula subsp. pichi-sermolliana Schwartsb. \& J. Prado for the highlands of central Africa and Bioko; and H. rugosula subsp. rugosula for Australia and Tasmania.

The present paper is a continuation of the abovementioned studies, treating nearly all populations of Hypolepis rugosula recognized to date, on the basis of the morphological and biogeographic data. We will show that $H$. rugosula is far more widely distributed than previously thought by Christensen $(1920$; 1932; 1937) and Christensen \& Skottsberg (1920), although not exactly as interpreted by others, such as Hooker (1862).

\section{Material and methods}

We analyzed 515 sheets of Hypolepis rugosula, obtained from the following herbaria: the Berlin-Dahlem Botanical Garden and Museum, in Berlin, Germany (code, B); the National Institute of Agricultural Technology, in Buenos Aires, Argentina (code, BAB); the University of Barcelona CeDoc Institute of Plant Biodiversity, in Barcelona, Spain (code, BCN); the National University of Comahue, in Río Negro, Argentina (code, BCRU); the Federal University of Minas Gerais, in Belo Horizonte, Brazil (code, BHCB); the Natural History Museum, in London, England (code, BM); the National Botanic Garden, in Meise, Belgium (code, $\mathrm{BR})$; the National University of Córdoba, in Córdoba, Argentina (code, CORD); the Natural History Museum, in Florence, Italy (code, FI), including the Pichi-Sermolli collection (FI-PS) and the Webb collection (FI-W); the Conservatory and Botanical Garden of the City of Geneva, in Geneva, Switzerland (code, G); the Rio Grande do Sul State Zoological Botany Foundation, in Porto Alegre, Brazil (code, HAS); the Bradeanum Herbarium, in Rio de Janeiro, Brazil (code, HB); the Royal Botanic Gardens, in Surrey, England (code, K); the Federal University of Rio Grande do Sul, in Porto Alegre, Brazil (code, ICN); the Leiden National Herbarium of the Netherlands, in Leiden, Netherlands (code, L); the V. L. Komarov Botanical Institute, in Saint Petersburg, Russia (code, LE); Saint Petersburg University, in Saint Petersburg, Russia (code, LECB); Museo de La Plata, in Buenos Aires, Argentina (code, LP); the Municipal Botanical Museum, in Curitiba, Brazil (code, MBM); the University of Oxford, in Oxford, England (code, OXF); the National Museum, in Prague, Czech Republic (code, PR); Charles University, in Prague, Czech Republic (code, PRC); the Rio de Janeiro Botanical Garden, in Rio de Janeiro, Brazil (code, RB); the National Museum of Natural History, in Santiago, Chile (code, SGO); the Botanical Museum, in Buenos Aires, Argentina 
(code, SI); the Botanical Institute of São Paulo, in São Paulo, Brazil (code, SP); the University of São Paulo Herbarium of Phanerogamae, in São Paulo, Brazil (code, SPF); the Utrecht National Herbarium of the Netherlands, (now) in Leiden, Netherlands (code, U); the Federal University of Paraná, in Curitiba, Brazil (code, UPCB); Uppsala University, in Uppsala, Sweden (code, UPS); the Federal University of Viçosa, in Viçosa, Brazil (code, VIC); the Natural History Museum, in Vienna, Austria (code, W); and the Museum of New Zealand Te Papa Tongarewa, in Wellington, New Zealand (code, WELT). Living specimens of $H$. rugosula subsp. pradoana were studied in nature, at four different locations in Brazil. The complete list of the material examined appears in Appendix 1. The isolated populations are defined here as subspecies. Below each subspecies listed in the main text, only representative specimens are cited. Drawings were made (Fig. 1). The map shown in Fig. 2 was constructed with Diva-Gis, version 7.5 (http://www.diva-gis.org/download), the coordinates having been estimated with Google Earth (http://www. google.com/earth/download/ge/agree.html).

\section{Results}

In analyzing specimens of Hypolepis rugosula from nearly everywhere it occurs, we observed the following:

- Hypolepis rugosula is a subcosmopolitan species, with isolated populations throughout the southern temperate regions and tropical regions (at the upper elevations), as well as on isolated oceanic volcanic islands.

- Hypolepis rugosula is a unique species characterized by a combination of morphological characters (some almost exclusive) that distinguish it from all other species in the world.

- The subspecies are best defined geographically, and none present any striking exclusive morphological character.

- There are four well-defined patterns of "indument" (referring to catenate and glandular hairscollectively), which can be noted as tendencies ascribed to the subspecies.

- Some morphological characters are linked to local ecological factors and can vary within each subspecies, especially the frond size; the composition and thickness of the lamina; and the indument (thus the divisions among the four indument patterns are sometimes blurred).

- There are at least two successful lineages of Hypolepis rugosula: one tetraploid and one octoploid. The ploidy level seems unrelated to the indument pattern.

- Long-distance dispersal is the most likely explanation for the extant distribution of Hypolepis rugosula around the world, especially on the volcanic islands. However, we do not exclude the possibility of vicariance among the land masses that were once united as Gondwana.

\section{Discussion}

\section{Morphology}

\section{Characters used in the delineation of the taxa}

Morphology was the main basis of the species concept, from macroscopic features (e.g., size of the frond, color of the axis, laminar architecture) to anatomical features (e.g., stele and vascular bundles), microscopic features (e.g., development of the pseudoindusia) and the indument pattern as the finest feature (especially, the types of hair, their sizes, in which lamina region they are present, etc.) This species concept is almost in total accordance with the actual state of art (e.g., Bronwsey \& Chinnock 1984; 1987; Brownsey 1987; Moran 1995; Mickel \& Smith 2004; Schwartsburd 2012b; Schwartsburd \& Prado unpublished data).

The sensitive difference of the present paper in relation to those cited above (and others) is that it accepts a morphological plasticity within Hypolepis rugosula - not only among the subspecies but especially within each subspecies. Although the indument is a reliable taxonomic character for most Hypolepis species, it must be carefully analyzed in $H$. rugosula. Individuals of $H$. rugosula typically bear both catenate-acicular and catenate-glandular hairs. However, the density of those hairs, as well as their number and position in the laminar regions, and even the co-occurrence of the two types of hair, are sometimes linked to local ecological factors.

Hypolepis rugosula is easily recognized by the color of the main axes (petioles, rachises, and pinna-rachises), which are burgundy (see Schwartsburd 2012b: Fig. 3D). This is almost an exclusive character, shared only with $H$. distans Hook. (a quite unique species); in all other species, the color is brown, ranging from straw-colored to dark brown (in a few species, they are purple, although only at the base of the petioles). Another feature that is probably exclusive is the vascular bundle of the petioles, which is proximally pi-shaped, and distally split into two S-shaped bundles. The other species present mostly omega-shaped vascular bundles proximally, distally splitting into many bundles (details in Schwartsburd 2012a; Schwartsburd \& Prado unpublished data). In addition to these two features, the combination of the following characters serves to distinguish $H$. rugosula from all other species in the world: fronds small to medium in size-(15.0-)60.0-140.0 $\times(4.0-) 20.0-50.0(-60.0) \mathrm{cm}$, main axes rugose and inermous, proximal pinnae equilateral and distant from the next pair, sori submarginal, pseudoindusia absent (the lamina margins occasionally revolute, protecting the sori, but never differentiated into hyaline flaps), and indument typically composed of catenate-acicular and catenateglandular hairs (plus some brown hairs similar to those of the rhizome present throughout the main axes) - Fig. 1, A-R; see also Schwartsburd (2012b: Fig. 2). 


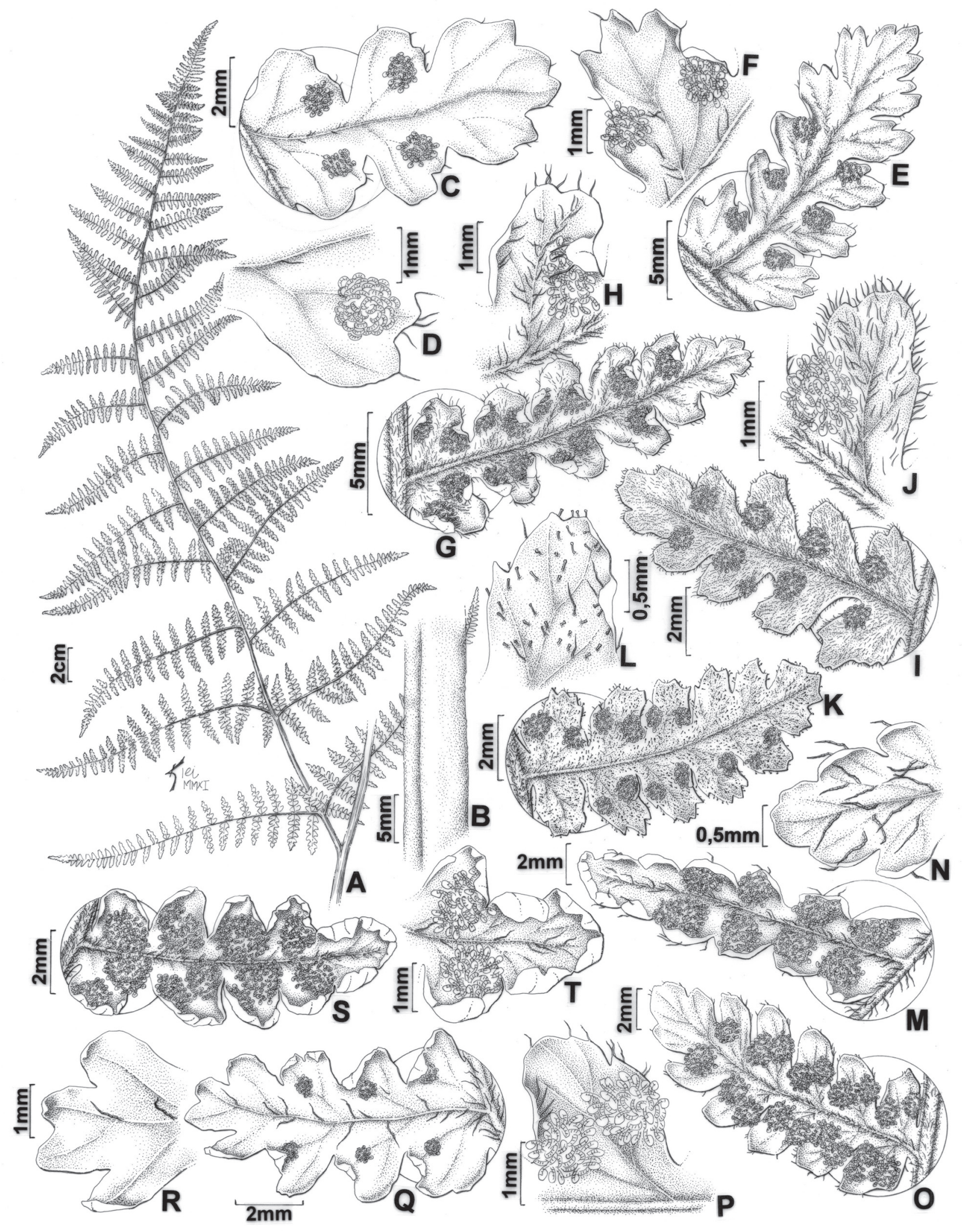

Figure 1. Some subspecies of Hypolepis rugosula (Labill.) J. Sm.: A, B-subsp. poeppigiana (Mett.) Schwartsb. \& J. Prado (Sota 2764); C, D-subsp. pradoana Schwartsb. (Brade 15540); E, F-subsp. poeppigiana (Mett.) Schwartsb. \& J. Prado (Diem 702); G, H-subsp. poeppigiana (Mett.) Schwartsb. \& J. Prado (Parra 106); I, J-subsp. rufobarbata (Colenso) Schwartsb. (Knight s.n. [RB 215825 b]); K, L-subsp. lactea (Brownsey \& Chinnock) Schwartsb. (Knight s.n. [RB 215825 a]); M, N-subsp. rudis (Kunze) Schwartsb. (Cuming 140); O, P-subsp. rugosula (Burbidge 7423); Q, R-subsp. africana (C. Chr.) Schwartsb. \& J. Prado (de MontBizon s.n. [RB, ex Fée]); S, T—subsp. viscida (Roxb.) Schwartsb. \& J. Prado (Cuming 433). 


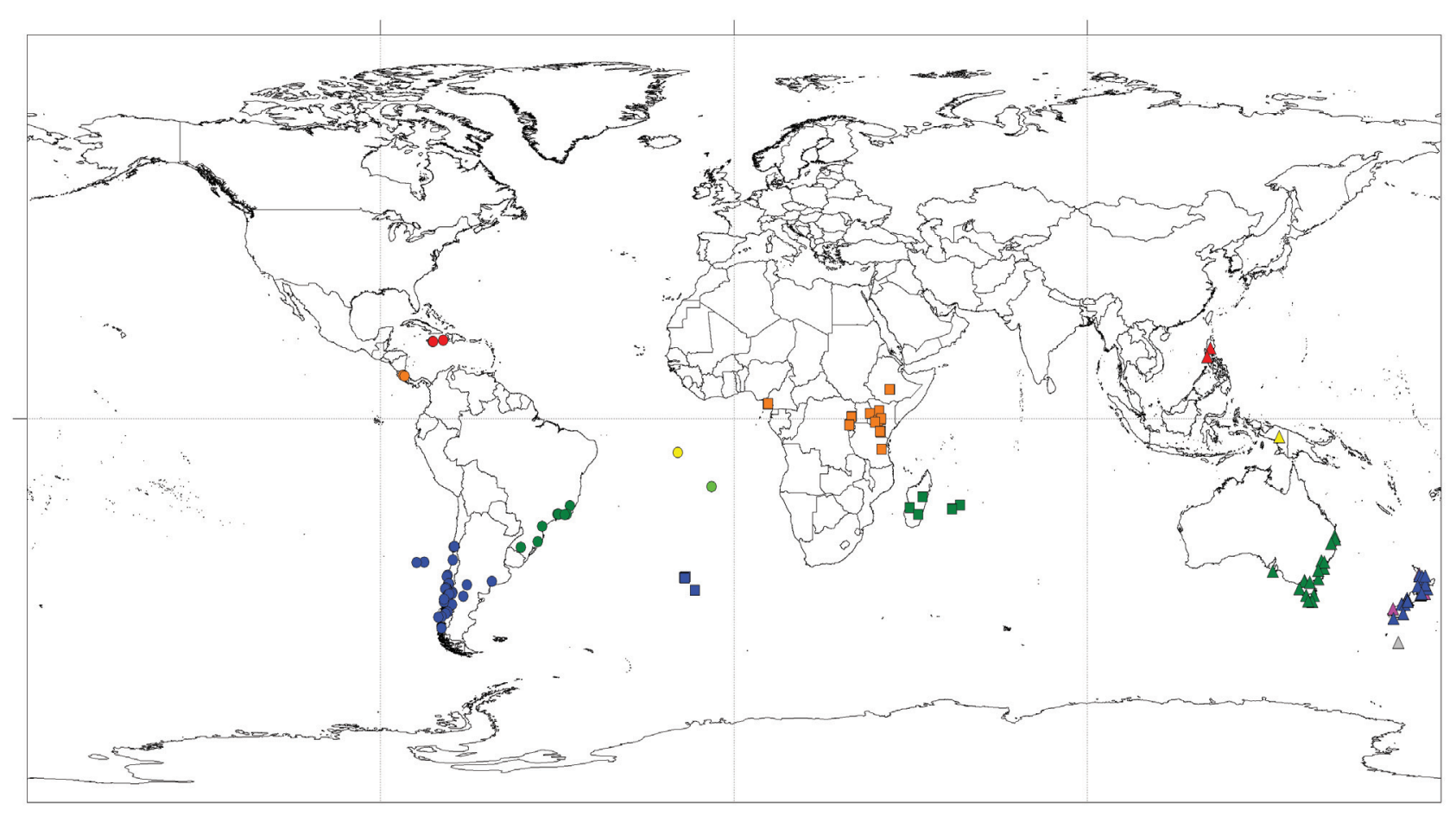

Figure 2. World map showing the distribution of the subspecies of Hypolepis rugosula (Labill.) J. Sm.: red circle—subsp. pulcherrima (L.M. Underw. \& Maxon) Schwartsb. \& J. Prado; orange circle-subsp. colorata (H. Christ) Schwartsb. \& J. Prado; blue circle-subsp. poeppigiana (Mett.) Schwartsb. \& J. Prado; green circle—subsp. pradoana Schwartsb.; yellow circle—subsp. brownseyana Schwartsb. \& J. Prado; bright green circle—subsp. viscida (Roxb.) Schwartsb. \& J. Prado; blue square - subsp. villoso-viscida (Thouars) Schwartsb. \& J. Prado; orange square-subsp. pichi-sermolliana Schwartsb. \& J. Prado; green square-subsp. africana (C. Chr.) Schwartsb. \& J. Prado; red triangle-subsp. rudis (Kunze) Schwartsb.; yellow triangle—subsp. archboldii (Copel.) Schwartsb.; green triangle-subsp. rugosula; blue triangle - subsp. rufobarbata (Colenso) Schwartsb.; pink triangle - subsp. lactea (Brownsey \& Chinnock) Schwartsb.; gray triangle - subsp. subantarctica (Brownsey \& Chinnock) Schwartsb (colors only in PDF version).

\section{Morphological plasticity within an isolated population}

Sizes and degree of lamina division. Possibly, the frond sizes and degree of lamina division are related to the length and width of the rhizomes, and thus to the age of the plants. For example, mature fertile fronds of Hypolepis rugosula subsp. pradoana can be found ranging from $15.0 \mathrm{~cm}$ long, with pinnate-pinnatisect laminae (Labiak 4778 [UPCB]), up to $95.0 \mathrm{~cm}$ long, with bipinnate-bipinnatisect lamina (Schwartsburd 2310 [VIC]) - see also Schwartsburd (2012b: Fig. 2). Similar variation can be observed on plants from Tristan da Cunha, for example: fronds $25.0 \mathrm{~cm}$ long, with pinnate-pinnatisect lamina (Rogers [K-000369143]); and fronds up to $60.0 \mathrm{~cm}$ long, with pinnate-bipinnatisect lamina (Mejland $1158[\mathrm{~K}]$ ).

Lamina width and indument. Specimens from caves, or rocky/sheltered sites usually have thinly membranous laminae, almost flaccid, sparsely pilose to glabrous or completely glabrous. This can be seen, for example, in Tristan da Cunha (Rogers [K-000369141]), southeastern Brazil (Brade 15540 [RB]-Fig. 1, C and D) and the Juan Fernandez Islands (Sparre s.n. [K], Meyer $9536[\mathrm{~K}]$ ). However, specimens from open sunny areas tend to present laminae that are thicker, subchartaceous and much more densely pilose- see also the discussion of Christensen \& Skottsberg (1920).

\section{Indument patterns}

The four basic indument patterns are easily distinguished, although the divisions between them can be blurred in specimens from sheltered places, which tend to present glabrescent or glabrous laminae, or in juvenile fronds, which tend to be much hairier. Apart from those exceptions, the four indument patterns are constant for most specimens of each subspecies of Hypolepis rugosula:

Typical. In the typical pattern, the laminar tissue between the veins is abaxially glabrous or nearly glabrous; laminar margins with catenate-acicular and catenate-glandular hairs sparsely throughout (Schwartsburd 2012b: Fig. 2 ), or with only catenate-acicular hairs, especially notable near the soral region (Fig. 1, C-H, O and P). This type is found in most subspecies: colorata, poeppigiana, pradoana, pulcherrima, rugosula and subantarctica.

Lacteal. In the lacteal pattern, the laminar tissue between the veins, abaxially, has conspicuous short catenateglandular hairs; laminar margins copiously furnished with only catenate-glandular hairs (Fig. $1 \mathrm{~K}, \mathrm{~L}$ ). This pattern is found only in the subspecies lactea.

Rufobarbata. In the rufobarbata pattern, the laminar tissue between the veins, abaxially, has conspicuous reddish catenate-acicular hairs; laminar margins copiously 
furnished with reddish catenate-acicular hairs (Fig. 1, I and J). This pattern is found in the subspecies archboldii, rufobarbata and villoso-viscida.

Africana. In the africana pattern, the laminar tissue between the veins is abaxially glabrous; laminar margins glabrous (Fig. $1, \mathrm{M}, \mathrm{N}$ and $\mathrm{Q}-\mathrm{T})$. This pattern is found in the subspecies africana, brownseyana, pichi-sermolliana, rudis and viscida.

In the other lamina regions, the four indument patterns are similar: main axes with catenate-acicular and catenateglandular hairs (Fig. 1, C-T; Schwartsburd 2012b: Fig. 2); laminar tissue between the veins adaxially mostly with catenate-acicular hairs and sparse catenate-glandular hairs (Schwartsburd 2012b: Fig. 2C).

\section{Cytology and ploidy}

For the genus Hypolepis, the monoploid chromosome number $(x)$ and haploid chromosome number $(n)$ are 52 and $104(2 n=104$ and 208), respectively, where the latter number is likely attributable to tetraploidy (Brownlie 1957; Manton \& Vida 1968; Smith \& Mickel 1977; Brownsey 1983). Brownsey (1983) further suggested that the basic number would be an extinct $x=26$ from a hypothetical ancestor, based on other Dennstaedtiaceae genera, and the "abnormal" species $H$. distans $(n=28)$ and $H$. nigrescens Hook. $(n=29)$ would have arisen from alloploidy. Following this idea, the extant regular species would have arisen from tetraploidy $(4 n=104)$ or octoploidy $(8 n=208)$.

Regarding the Hypolepis rugosula complex, Brownsey \& Chinnock (1984) counted $n=52$ for two specimens from New Zealand, which present the rufobarbata indument pattern (Brownsey NZ 1435 from North Island) and the typical indument pattern (Brownsey s.n. [WELT-P11518 A and B], from Campbell Island). Following Brownsey (1983, $x$ $=26$ ), those numbers would represent tetraploid lineages $(4 n=104)$. Because the two specimens present two distinct indument patterns, it is reasonable to suggest that the ploidy level is unrelated to the indument pattern.

Other chromosome counts were made by Manton \& Vida (1968), who presented the numbers $2 n=208$ for Tristan da Cunha specimens, and $n=\approx 100$ for those from Gough Island. Such numbers would then represent octoploid lineages $(8 n=208)$. The one specimen analyzed in the present study (Manton 5/66, 4/66 [BM]) presents the rufobarbata pattern of indument.

Although it is too early to draw definitive conclusions, there are apparently at least two successful lineages within the Hypolepis rugosula complex (one tetraploid and one octoploid), and the ploidy level is probably unrelated to the indument pattern.

\section{Biogeographic hypotheses and the adoption of subspecific rank}

As many authors have argued (Brownsey 2001; Parris 2001; Wolf et al. 2001; Moran 2008), the distribution of fern taxa can be inferred to have happened by vicariance, dispersal or a combination of the two. Dispersal is the more widely accepted explanation, because ferns famously disperse their microspores by wind. Long-distance dispersal is also well accepted by the scientific community, being a common explanation for the origins of island floras (Tryon 1970; Moran 2008). However, vicariance tends to be avoided as an explanation for phenomena such as the Gondwana relationships. That is primarily due to our limited knowledge of the relationship between extant and extinct genera; often, "dispersal obscures evidence of vicariance" (Wolf et al. 2001). Because vicariance is avoided for explaining the distribution of families and genera, it is almost completely rejected at the species level.

The Dennstaedtiaceae is an extant cosmopolitan family that is one of the oldest families of leptosporangiate ferns (Smith et al. 2008). The oldest known fossils are at least 75 Myr old (Serbert \& Rothwel 2003), from Canada. Although little is known about the Gondwana fossils, the family appeared in New Zealand at least 30 Mya (Mildenhall 1980, cited in Brownsey 2001) - before Gondwana had fully separated. Among its eleven extant genera, seven are subcosmopolitan (or at least amphitropical or circum-Antarctic): Blotiella R.M. Tryon, Dennstaedtia Bernh., Histiopteris J. Agardh, Hypolepis Bernh., Microlepia C. Prel, Paesia A.St.Hil., and Pteridium Gled. ex Scop. (Tryon \& Tryon 1982; Kramer 1990; Parris 2001; Smith et al. 2008). Some of its species present similar distribution: Histiopteris incisa (Thunb.) J. Sm. and Microlepia speluncae (L.) T. Moore are circum-Antarctic reaching the tropics (Parris 2001); Hypolepis rugosula is subcosmopolitan (Fig. 2; present paper); and Pteridium aquilinum (L.) Kuhn is cosmopolitan (sensu Tryon 1941).

The genus Pteridium is thought to contain only one species (Tryon 1941); two/three species, as well as two hypothetical allotetraploid species (Der et al. 2009; Thomson 2012); or up to a dozen species (Mickel \& Smith 2004). There are also many infraspecific classifications that, in the interest of brevity, will not be discussed here. Nevertheless, the genus Pteridium is cosmopolitan and widely distributed throughout its range, and its isolated populations (= morpho-taxa: species, subspecies, or varieties) are interconnected. Therefore, it is reasonable to assume that its current distribution occurred by vicariance (see extensive discussion in Wolf et al. 2001: 267).

What about Microlepia strigosa, Histiopteris incisa and Hypolepis rugosula? Although they do present current subcosmopolitan distributions, their populations are all isolated from each other (Fig. 2). In addition, they seem quite rare in nature (our personal observation throughout Brazil). Certainly, no one has ever seriously considered these distributions to be a result of Gondwana vicariance but rather of long-distance dispersal. Would one species remain unchanged for more than 70 Myr? Or, even if speciation has occurred, would the same "successful design" be 
maintained unchanged for $70 \mathrm{Myr}$ in "cryptic species"? And furthermore, could three species within the same family share a coincidental "cryptic pattern"? One way to support the vicariance hypothesis for these three species is to invoke and adapt the Haffer-Vanzolini theory of refugia (Haffer 1992). These three Dennstaedtiaceae species currently occur in relatively southern temperate regions, including tropical regions, although their distribution in the latter is mostly limited to the upper elevations-commonly at $\geq$ $1000 \mathrm{~m}$ in subtropical regions, and at $\geq 2000 \mathrm{~m}$ in tropical regions (Brade 1956; Mickel \& Smith 2004; Schwartsburd \& Prado 2011; Schwartsburd 2012b). This is a common biogeographic pattern in which there is a similarity between upper elevations and the upper latitudes. It was conceived by the earliest biogeographers, such as Tournefort and Linnaeus (Papavero et al. 2013: Chap. 6), who termed it "altitudinal climatic zonation". Therefore, even though these species inhabit tropical regions, their occurrence is limited to temperate conditions. With this in mind, we can speculate that these species were more widely distributed during times when the Earth was cooler (e.g., the last ice age) and are now relicts, restricted to cold refugia, as a result of climatic vicariance. Obviously, to interpret the current distribution of these three species as resulting from long-distance dispersal still seems much more reasonable, especially because they occur sympatrically on isolated oceanic volcanic islands (e.g., Tristan da Cunha, Gough and Saint Helena). Given that volcanic islands are "young", their colonization by these species almost certainly occurred through long-distance, the spores traveling thousands of kilometers across the oceans to germinate and establish new populations. These plants seem adapted to long-distance dispersal. How many times such dispersal could have occurred is a question that cannot yet be answered. Did it occur during isolated events, such as the passing of super-hurricanes or El Niño? Do the populations often disperse their spores across the oceans on air masses or via jet streams? It is still too early to draw any conclusions about the origins of their distribution, which could be attributable to a combination of vicariance and dispersal.

Our basic hypothesis is that vicariance, dispersal or both occurred a long time ago and (in the case of dispersal) only a few times, thus providing a sufficient amount of time for the isolated populations of Hypolepis rugosula to start the process of speciation but not enough time for them to actually differentiate into separate species (given that they are still so similar). With this hypothesis in mind, we have recognized the geographically isolated populations as subspecies of $H$. rugosula.

\section{The New Zealand hypothesis}

Apart from the local ecological plasticity of indument, most subspecies of Hypolepis rugosula are quite homogeneous. The only place where two distinct patterns of indument (rufobarbata and lacteal) can be found is in New Zealand (on the North and South Islands, respectively). For New Zealand, we are adopting a secondary hypothesis: $H$. rugosula arrived there at two different times (on the South Island and on the North Island) and then became two well-defined isolated populations (subspecies), having now encountered each other and bred, creating "hybrids" (Brownsey \& Chinnock 1984).

\section{Taxonomic treatment}

Hypolepis rugosula (Labill.) J. Sm., Bot. Mag. 3rd ser., 2: 8. 1846, as "rugulosa". Polypodium rugosulum Labill., Nov. Holl. Pl. 2: 92, t. 241. 1806 [1807?]. Phegopteris rugosula (Labill.) Fée, Gen. Filic.: 243. 1852, as "rugulosa". Polypodium punctatum Thunb. var. rugosulum (Labill.) Hook. \& Baker, Syn. Fil.: 312. 1867, as "rugulosum". Dryopteris punctata (Thunb.) C. Chr. subsp. rugosula (Labill.) C. Chr., Index Filic.: 287. 1905. Phegopteris punctata (Thunb.) Mett. var. rugosula (Labill.) Hillebr., Fl. Hawaiian Island (Hillebrand): 563. 1888, as "rugulosa". Dryopteris punctata (Thunb.) C. Chr. var. rugosula (Labill.) Domin, Biblioth. Bot. 85: 41.1913. Hypolepis rugosula (Labill.) J. Sm. var. rugosula C. Chr. \& Skottsb. in Skottsb., Nat. Hist. Juan Fernandez (Botany): 32. 1920, as "var. typica". Lectotype (designated by Pichi-Sermolli 1983: 260, and by Schwartsburd \& Prado 2011: 157): [Tasmania], Habitat in Capite Van-Diemen, [1791-1793], Labillardière s.n. (FI-W!-214897; isolectotypes: FI-W!-214898, FI-W!214899, FI-W!-on 2 sheets [214903, 214904], FI-W!-216239, FI-W!-218473, G!-on 2 sheets [00048249, 00048250], G!-on 2 sheets [00048252, 00048253], G!-00048255, LE!-2 sheets; probable isolectotypes: B! [ex Herb. Mertens], G!-00048251, K!, L!- 908837-403, PRC!). Fig. 1A-T.

Plants terrestrial, humicolous or epipetric. Rhizomes solenostelic and siphonostelic, (1.2-) 2.0-4.0 mm diam., lanose, the hairs catenate-acicular, yellowish to reddishbrown, 1.0-3.0(-4.0) mm long, 15-30-celled. Fronds erect or arched, with continuous growth, (15.0-)60.0-140.0 $\mathrm{cm}$ long; petioles (6.0-)20.0-50.0 cm $\times(0.8-) 1.5-4.0 \mathrm{~mm}$, proximally with one pi-shaped stele, distally with two Sshaped steles, burgundy, inermous, rugose, abaxially and adaxially sparsely villous with three or four kinds of hairs, the first kind of hair catenate-acicular, hyaline with reddish cross-walls, 0.3-0.7 mm long, 5-10-celled, the second catenate-glandular, hyaline with reddish cross-walls, 0.3 $0.7 \mathrm{~mm}$ long, 5-10-celled, the third similar to those from the rhizomes, sparse and caduceus, the fourth (only in the rufobarbata pattern) catenate-glandular, entirely yellowishbrown, 1.0-2.5 mm long, 10-20-celled, scattered; laminae lanceolate or ovate, proximally pinnate-pinnatisect with segments pinnatifid up to bipinnate-bipinnatisect with pinnatifid segments, medially less decompound, distally pinnatisect, (10.0) 40.0-95.0 × (4.0-)20.0-50.0(-60.0) cm, with the two basal pair of pinnae much more distant from each other than from those above; rachises straight, burgundy throughout, or proximally burgundy and straw-colored 
above, inermous, rugose, the indument similar to the petioles but the hairs more numerous, especially on the adaxial groove; proximal pinnae (2.0-)12.0-30.0 × (1.5-)4.0-12.0 $\mathrm{cm}$, equilateral; costae abaxially sparsely villous, adaxially copiously villous, the hairs similar to those on the petioles and rachises but the third (and fourth) kind(s) usually absent or very scattered; costules abaxially and adaxially with the first and second kinds of hairs, or rarely with only the first or the second kind, shorter, $0.2-0.5 \mathrm{~mm}$ long, 4- to 7-celled; veins with the indument similar to the costules; laminar tissue between the veins abaxially glabrous or nearly glabrous (typical and africana-types), with the first kind of hair (rufobarbata pattern), or with the second kind (lacteal pattern), adaxially with both the first and second kinds of hair, ca. 0.2-0.3 mm long, 3- or 4-celled; lamina margins glabrous, with the first or second kind of hair, occasionally with both, similar in size to those on the laminar tissue between the veins; sori submarginal, unprotected or slightly protected; pseudoindusia absent, the lamina margin sometimes slightly revolute, protecting the sori, but never differentiated into a hyaline flap.

Distribution and ecology: Subcosmopolitan. The populations are segregated from each other (Fig. 2): Tasmania and Australia; New Zealand; the highlands of New Guinea; Luzon (the Philippines); Santa Helena Island; Ascension Island; Madagascar, Réunion Island, and Mauritius; Bioko and the highlands of central Africa (the Democratic Republic of Congo, Ethiopia, Uganda, Kenya, Tanzania and Rwanda); the islands of Tristan da Cunha and Gough; central and southern Argentina and Chile (including the Juan Fernandez Islands); the highlands of southern and southeastern Brazil; the highlands of Costa Rica; and the highlands of Mexico, Jamaica and Hispaniola. At sea level and above in temperate regions; above ca. $1000 \mathrm{~m}$ in subtropical regions; and above ca. $2000 \mathrm{~m}$ in tropical regions, having been reported at 3450 $\mathrm{m}$ and $3560 \mathrm{~m}$, respectively, in Uganda and New Guinea.

\section{Enumeration of the subspecies}

Table 1 summarizes the subspecies considered here, their respective distribution and the pattern of indument. We present the subspecies taxonomically, on the basis of our examination of the representative materials, and provide details of their distribution.

1. Hypolepis rugosula (Labill.) J. Sm. subsp. pulcherrima (L.M. Underw. \& Maxon) Schwartsb. \& J. Prado, stat. nov. for Hypolepis pulcherrima L.M. Underw. \& Maxon in Maxon, Proc. Biol. Soc. Wash. 43: 84. 1930, based on the description of Jenman, Bull. Bot. Dept. Jamaica 36: 10. 1892, sub "Hypolepis purdieana Hook". Lectotype (re-designated here): JAMAICA. Blue Mt. Range, elev., 7000 ft, VII/1878, Jenman $72(\mathrm{~K} !)$.

Distribution and ecology: Mexico, elev., 2100-2900 m (cited in Mickel \& Smith 2004, no material seen); Jamaica and
Hispaniola (Haiti), elev., 1500-2500 m.

Indument pattern: Typical.

Representative specimens examined: JAMAICA. Blue Mountain Peak, elev., 6500 ft, X/1952, Proctor 7222 (U); Parish of St. Thomas, $18^{\circ} 02^{\prime} \mathrm{N}$; $76^{\circ} 36^{\prime} \mathrm{W}$, elev., ca. $1680 \mathrm{~m}$, VII/1991, Bellingham 1536 (BM). HISPANIOLA. Haiti: Massif de la Rotte, elev., 2375 m, IX/1928, Ekman, Pl. Ind. Occid. H 10636 (BM).

Underwood \& Maxon (1930) described Hypolepis pulcherrima as a new taxon indicating the description provided by Jenman (1892) for "Hypolepis purdieana Hook." - valid published under the International Code of Botanical Nomenclature (ICBN) art. 32.5 (ICBN 2006). Later, Lellinger (1977: 716) chose as lectotype one material cited by Underwood \& Maxon (1930): Maxon 9912 (US-on 4 sheets [image!]). According to ICBN (2006: art. 9.17), Lellinger should have chosen an original material of Jenman, if in existence. Thus, we here redesignate the lectotype: Jenman 72 (K!).

2. Hypolepis rugosula (Labill.) J. Sm. subsp. colorata (H. Christ) Schwartsb. \& J. Prado, stat. nov. for Hypolepis repens (L.) C. Presl var. colorata H. Christ in Pittier, Prim. Fl. Costar. 3(1): 37. 1901. Lectotype (designated here): COSTA RICA. Forêts au dessus de l'Achiote, au volcan de Poás, elev., 2000[-2200] m, XI/1896, Tonduz 10704 (BR!; isolectotypes: G!-2 sheets [ex Herb. Boissier], G! [ex Herb. Dellesert], LE! [ex Herb. Inst. Phys.-Geogr. C.R.], LE! [ex Herb. Pittier \& Durand], LE! [ex Herb. Tonduz], P-n.v.).

Distribution and ecology: Costa Rica, elev., 2000-2500 m. Indument pattern: Typical.

Specimens examined: COSTA RICA. Alto del Sacatal, elev., 2500 m, I/1897, Pittier 10529 (BR!, P-2 sheets-n.v.-syntypes of $H$. repens var. colorata); Volcan Poas, elev., 2300 m, III/1896, Smith 6861 (B, G, K).

3. Hypolepis rugosula (Labill.) J. Sm. subsp. poeppigiana (Mett.) Schwartsb. \& J. Prado, stat. nov. for Hypolepis poeppigiana Mett. in Hohen., Fil. Lechler. 1: 18. 1856. Lectotype (designated here): CHILE. [Los Ríos]: prope coloniam Arique in prov. Valdivia, V/1851, Lechler, Pl. Chil. 194 (B!-20 0074790; isolectotypes: B!-20 0074789, B!-20 0074791, FI!, FI-W!-214914, G!-on 2 sheets, GOET-n.v., K!-000640324, K!-000640325, K!-000640326, L!, LE!-2 sheets, UPS!, W!). Fig. 1, A, B and E-H.

Hypolepis chilensis Fée, Ic. Sp. Nouv.: 76.1857 [1858?], nom. superfl. Syntypes: CHILE. [Valparaíso]: Valparaiso, [1834 or 1835], Gaudichaud s.n. [31?] (BR!, FI-W!-214906, FIW!-214910, FI-W!-216216, G!, RB!, W!; probable duplicate: FI-W!-214917). CHILE. San Juan Fernandez, s.d., Gay (P?-n.v., PC?-n.v.). CHILE. [Los Ríos]: près de la colonie Arique, province de Valdivia, [V/1851], Lechler [Pl. Chil. 194] (B!-3 sheets [20 0074789, 200074790,200074791$]$, FI!, FI-W!-214914, G!-on 2 sheets, GOET-n.v., K!-000640324, K!-000640325, K!-000640326, L!, LE!-2 sheets, UPS!, W!). Phegopteris poeppigii (Kunze) Fée ex Gay var. hirsuta Phil., 
Table 1. The subspecies of Hypolepis rugosula (Labill.) J. Sm., their distribution, and their indument pattern.

\begin{tabular}{cccc}
\hline & Subspecies & Distribution & Indument \\
\hline 1 & pulcherrima & Mexico, Jamaica, and Hispaniola & Typical \\
2 & colorata & Costa Rica & Typical \\
3 & poeppigiana & Central/southern Argentina and Chile (including the Juan Fernandez Islands) & Typical \\
4 & pradoana & Southern/southeastern Brazil & Typical \\
5 & villoso-viscida & Tristan da Cunha and Gough Islands & Rufobarbata \\
6 & viscida & Saint Helena Island & Africana \\
7 & brownseyana & Ascension Island (Saint Helena) & Africana \\
8 & pichi-sermolliana & Central Africa and Fernando Po Island (Bioko) & Africana \\
9 & africana & Madagascar, Reunion Island, and Mauritius & Africana \\
10 & rudis & Luzon (the Philippines) & Africana \\
11 & archboldii & New Guinea & Rufobarbata \\
12 & rugosula & Australia and Tasmania & Typical \\
13 & lactea & New Zealand & Lacteal \\
14 & rufobarbata & New Zealand & Rufobarbata \\
15 & subantarctica & Auckland and Campbell Islands & Typical \\
\hline
\end{tabular}

Anales Univ. Chile: 583.1873 [1872?]. Lectotype (designated here): [CHILE]. Puerto Lagunas, I/1872, Simpson s.n. (SGO000000467 [image!]).

Hypolepis hauman-merckii Hicken, Anal. Soc. Cient. Arg. 62: 212, t. s.n. 1906. Lectotype (designated here): ARGENTINA. Prov. Buenos Aires: Sierra de la Ventana, 25/XII/1905, Hauman-Merck s.n. (SI-000095 [image!]).

Distribution and ecology: Central/southern continental Argentina and Chile, including the Juan Fernandez Islands (Más a Tierra and Más Afuera), and Chiloé Islands; elev., sea level up to ca. $800 \mathrm{~m}$.

Indument pattern: Typical.

Representative specimens examined: ARGENTINA. Buenos Aires: Celle du Tandil, s.d., Hauman-Merck s.n. (SI?n.v.-syntype of Hypolepis hauman-merckii). Neuquén: Correntoso, I/1935, Cabrera \& Job 227 (LP). [Rio Negro]: Puerto Blest, XI/1997, Puntieri 396 (BCRU). CHILE. [Coquimbo]: Bosque Fray Jorge, elev., 500 m, VII/1938, Andreas 856 (L, U). [Valparaíso]: Valparaiso, s.d., Anonymous, n. 562 (W). [Bío-Bío]: Concepción, s.d., Philippi s.n. (K). [La Araucanía]: Prov. Cautín, Telmuco, 3843'S; 72³5’W, elev., 150 m, VII/1939, Montero 3696 (G). [Los Ríos]: Prov. Valdivia, II/1935, Hosseus 113 (CORD). [Los Lagos]: Prov. Palena, I/1986, Pedersen 14329 (BR, MBM). [Aisén Gen. Carlos Ibañez del Campo]: Patagonia Occid., Golfo de Peñas, VI/1908, Skottsberg 302 (UPS). Magallanes: Puerto Edén, VII/1970, Parra 106 (INTA). CHILE, JUAN FERNÁNDEZ. Más a Tierra: Valle Colonial, XII/1916, Skottsberg \& Skottsberg 120 (K, UPS). Más Afuera: Quebrada del Mono, elev., 400 m, II/1917, Skottsberg \& Skottsberg 439 (UPS). CHILE, CHILOÉ. Chiloé [Isla Grande de Chiloé]: s.d., Cap. King s.n. (K); [Dalcahue], Piruquina, X/1931, Junge 32 (PRC, SI).
4. Hypolepis rugosula (Labill.) J. Sm. subsp. pradoana Schwartsb., Kew Bull. 67(4): 818, figs. 2A-E, 3C-D. 2012. Type: BRAZIL. Rio de Janeiro: Teresópolis, Parque Nacional da Serra dos Órgãos, Matas Nebulares and Campos de Altitude, Pedra do Sino, near Abrigo Quatro, on the way to the water $\operatorname{tank}, 22^{\circ} 27^{\prime} 42^{\prime \prime} S$; 4301'50"W, elev., $2120 \mathrm{~m}$, 07/I/2011, Schwartsburd \& Pereira 2310 (holotype: SP!-on 3 sheets; isotypes: B!, FI!, G!, K!-on 3 sheets, LP!, NY!-on 2 sheets, P!-on 2 sheets, PRC!, RB!-on 2 sheets, SI!, SP!, UC!, UPCB!, VIC!, WELT!). Fig. 1, C and D.

Distribution and ecology: Highlands of southern/southeastern Brazil; elev., 1200-1800 m (southern Brazil) and 2000-2600 m (southeastern Brazil).

Indument pattern: Typical.

Representative specimens examined: BRAZIL. Minas Gerais: Passa Quatro, Itaguaré, elev., 2000 m, V/1948, Brade \& Araújo 19100 (RB). Rio de Janeiro: Itatiaia, P.N. Itatiaia, 22²1'47"S; 4443'39”W, elev., 2200 m, VII/2009, Schwartsburd et al. 2197 (SP, VIC). Paraná: Campina Grande do Sul, P.E. Pico do Paraná, 25²15'S; 4850’W, [elev., 1876 m], VII/2008, Labiak et al. 4778 (UPCB). Santa Catarina: Timbé do Sul, Serra da Rocinha, [elev., 1200 m], XI/1991, Bueno s.n. (ICN-155000). Rio Grande do Sul: Santa Cruz, XI/1911, Jürgens 352, Rosenst. Fil. Austrobras. Exsic. II 77 (B).

5. Hypolepis rugosula (Labill.) J. Sm. subsp. villoso-viscida (Thouars) Schwartsb. \& J. Prado, comb. nov. et stat. nov. for Polypodium villoso-viscidum Thouars, Esquisse Fl. Tristan d'Acugna: 33. 1803[1808]. Hypolepis rugosula var. villosoviscida (Thouars) C. Chr., Sci. Results Norweg. Antarct. Exped. 1927-1928, n. 16: 15. 1937. Hypolepis villoso-viscida (Thouars) Tardieu in Humbert, Fl. Madagasc. 5(Polypodiacées, Tome 1): 6, f. I.3-5. 1958. Holotype: TRISTAN DA 
CUNHA. s.d., Petit-Thouars s.n. (P-00522442 [image!]). Cheilanthes viscosa Carmich., Trans. Linn. Soc. London 12(2): 511.1818 [1819], nom. superfl. (for including Polypodium villoso-viscidum Thouars in synonymy). Lectotype (designated by Groves 1981: 404): ISLAND OF TRISTAN DA CUNHA. In the Wood, s.d., Carmichael s.n. (K!000369140; isolectotype: BM!).

Distribution and ecology: Tristan da Cunha island group: Tristan da Cunha, Inaccessible, Nightingale and Gough; elev., sea level up to $400 \mathrm{~m}$.

Indument pattern: Rufobarbata.

Representative specimens examined: TRISTAN DA CUNHA. Above Sandy Point, elev., 200 m, I/1938, Mejland 1158 (K, L); 1924, Rogers s.n. (K-000369143); [from Tristan da Cunha] cultivated at Kew Gardens, 1968, Manton 5/66, 4/66 (BM). INACCESSIBLE ISLAND. Central part of plateau, elev., 400 m, II/1938, Christophersen 2498 (K). NIGHTINGALE ISLAND. Trail to lake region, elev., 100 m, II/1938, Christophersen 2233 (K); In a cave, 1924, Rogers s.n. (K-000369141). GOUGH ISLAND. Slope above Glen Creek, elev., $40 \mathrm{ft}$, XII/1955, Wace 30 (BM); Creek banks on southern aspect of Tafel Koppie, $40^{\circ} \mathrm{S} ; 09^{\circ} \mathrm{W}$, elev., $270 \mathrm{~m}$, XI/1979, Roux 745 (K).

6. Hypolepis rugosula (Labill.) J. Sm. subsp. viscida (Roxb.) Schwartsb. \& J. Prado, comb. nov. et stat. nov. for Polypodium viscidum Roxb. in Beats., Tracts St. Helena [Beatson]: 319. 1816. Lectotype (designated here): SAINT HELENA. Sandy Bay, around stone dikes, 1813-1814, Roxburgh 191/1 (BM!). Fig. $1, S$ and $T$.

Cheilanthes remota Kunze, Analecta Pteridogr.: 36. 1837, nom. superfl. (for including Polypodium viscidum Roxb. in synonymy). Type: SANTA HELENA. s.d., Petersen (herb.?; possible type: BR! [Anonymous, ex Herb. Martii]).

Hypolepis helenensis Fée, Mém. Foug., 5. Gen. Fil.: 147. 1852. Lectotype (designated here): [SAINT HELENA]. Habitat in Insulâ Sanctae Helenae, [1841], Cuming 433 (RB!215823; isolectotypes: B!-20 0075256, B!-20 0075263, B!-20 0075264, B!-20 0075265, B!-20 0075268-, BM!, G!-2 sheets [ex Herb. Barbey-Boissier], G! [ex Herb. de Candolle], G! [ex Herb. Delessert], G! [ex Herb. Moricand], K!-000214965, K!-on 2 sheets [000350990 and 000350991], L!-0051757, L!-0051758-, LE!-2 sheets [ex Herb. Fischer], LE! [ex Herb. Petropol.], OXF!, UPS!, W! [ex Herb. Palat. Vindob], W! [ex Herb. Presl]).

Distribution and ecology: Saint Helena Island (Saint Helena); elev., commonly 600-820 m.

Indument pattern: Africana.

Representative specimens examined: SAINT HELENA. Valley near Willow Point, XII/1809, Burchell 191 (B, K); Diana's Peak, VII/1813, Roxburgh 23 (BM!-syntype of Polypodium viscidum?).

7. Hypolepis rugosula (Labill.) J. Sm. subsp. brownseyana Schwartsb. \& J. Prado, subsp. nov. Type: [SAINT HELENA].
Ascension Island: 1891?, Anonymous [unreadable] s.n. (holotype: K!-000650391).

Differs from Hypolepis rugosula subsp. rugosula by the glabrous (vs. pilose) lamina margins.

Distribution and ecology: Ascension Island (Saint Helena), elevation unknown (probably 400-800 m). Known only from the type collection.

Indument pattern: Africana.

Etymology: The subspecific epithet honors Dr. Patrick J. Brownsey, of the Museum of New Zealand, Te Papa Tongarewa Herbarium (WELT), who has made great contributions to pteridology, especially regarding the ferns of New Zealand and the Pacific. Dr. Brownsey has also reviewed in detail the Hypolepis species from those areas, expanding the knowledge and improving the understanding of this under-studied genus. Although our perception of the Hypolepis rugosula complex is somehow different than his, the present study is largely based on his works.

8. Hypolepis rugosula (Labill.) J. Sm. subsp.pichi-sermolliana Schwartsb. \& J. Prado, Webbia 66(2): 158, figs. 1, 2. 2011. Type: DEMOCRATIC REPUBLIC OF CONGO. Dorsale ad ovest Del Lago Kivu, Montagne di Shamulamba, crinale a sud del rifugio del Groupe de Montagne de Kivu, elev., ca. 2600 m, 23/X/1953, Pichi-Sermolli 4441 (holotype: FI-PS!-on 2 sheets [19686]; isotypes: FI-PS!-19441, FI-PS!-19665). Distribution and ecology: Bioko (Equatorial Guinea), elev., 600-2130 m; continental Central Africa (the Democratic Republic of Congo, Ethiopia, Uganda, Kenya, Tanzania and Rwanda), elev., ca. 1800-3450 m.

Indument pattern: Africana.

Representative specimens examined: BIOKO (EQUATORIAL GUINEA). Elev., 7000 ft, 1860, Maun 381 (K). DEMOCRATIC REPUBLIC OF CONGO. Kivu Nord, elev., 2700 m, VIII/1954, Stauffer 122 (K); Vissoke Volcano, elev., 10,500 ft, XII/1930, Burtt 3017 (K). ETHIOPIA. Bale Mountains, elev., 3400 m, II/1990, Miehe \& Miehe 2011 (K); Bale Massif, elev., 3000 m, III/1958, Eriksson F $87 b$ (FI-PS). UGANDA. Ruwenzori, Bujuku Valley, elev., 3450 m, IV/1948, Hedberg 646 (K); Western Province, Kigezi District, elev., 3000 m, XI/1954, Stauffer 783 (K). KENYA. Embu District, elev., 2350 m, XII/1972, Gillett \& Holttum 20098 (K); Mount Kenya, elev., 10,000ft, XII/1957, Verdcourt 2063 (K, W). TANZANIA. Tanganyika, Kilimanjaro, elev., 2900-2950 m, III/1934, Schlieben 4897 (B); S-Uluguru Mts., 2250-2350 m, XI/1972, Pócs \& Kornaīs 6828/J (FI-PS). RWANDA. Kareba, elev., 3050 m, X/1974, Auquier 4509 (FI-PS).

9. Hypolepis rugosula (Labill.) J. Sm. subsp. africana (C. Chr.) Schwartsb. \& J. Prado, Webbia 66(2): 161. 2011. Hypolepis rugosula var. africana C. Chr. ex C. Chr., Dansk Bot. Ark. 7 (Pteridoph. Madagascar): 121. Jun 1932. Hypolepis rugosula var. africana C. Chr. in H. Perrier, Cat. pl. Madag., Pterid.: 49. 1931 [Feb 1932], nom. nud. Hypolepis goetzei 
Hieron. ex Reimers in J. Mildbraed, Notizbl. Bot. Gart. Berlin-Dahlem 112(12): 189. 1934 (as "Goetzei"), nom. nov. et stat. nov for Hypolepis rugosula var. africana C. Chr. ex C. Chr. Lectotype (designated by Schwartsburd \& Prado 2011: 161): MADAGASCAR. Süd-Betsiléo, Wald von Ankafina, III/1881, Hildebrandt 4139 (B!-20 0075279; isolectotypes: B!-20 0075278, B!-20 0075283, BM!, LE!-2 sheets, P-2 sheets, G! [ex Herb de Candolle], G!-on 2 sheets [ex Herb. BarbeyBoissier], W!). Fig. 1, Q and R.

? Phegopteris boryana Mett. in Ettingsh., Farnkr. Jetztwelt: 161,162 , t. 98 , fig 2., t. 102, fig. 2, t. 103, fig. 4. 1865. Syntypes?: MAURITIUS. 1846-1848, Boivin s.n. (W!-133/7829, W!-133/78-30); RÉUNION. s.d., Bory de Saint-Vincent s.n. (RB!-frag. [215817]).

Distribution and ecology: Madagascar, Réunion Island and Mauritius; elevation unknown.

Indument pattern: Africana.

Representative specimens examined: MADAGASCAR. Tanala, s.d., Kitching s.n. (K! - syntype of Hypolepis rugosula var. africana); Pic d'Ivohibe, s.d., Humbert 3324 (BM!, C-n.v., P-n.v.-syntypes of H. rugosula var. africana). RÉUNION ISLAND [îLE BOURBON]. 1853, Boivin B 813 (FI, G); s.d., Cordemoy 41 (K).

10. Hypolepis rugosula (Labill.) J. Sm. subsp. rudis (Kunze) Schwartsb., comb. nov. et stat. nov. for Cheilanthes rudis Kunze, Bot. Zeit. 6(11): 213. 1848. Hypolepis rudis (Kunze) Mett. in Ettingsh., Farnkr. Jetztwelt: 160. 1865. Lectotype (designated here): [PHILIPPINES]. [Luzon]: in the Philippines, [Prov. Albay], [1841], Cuming 140 (B!-20 0075269; isolectotypes: B! [ex Herb. Koenpreuss], FI-W!, G! [ex Herb. Moricand], K!-000492488, K!-000492495, LE! [ex Herb. Fischer], LE! [ex Herb. Petropol.], OXF!, RB!, W! [ex Herb. Mus. Wien], W! [ex Herb. Palat. Vindob]). Fig. 1, M and N. Distribution and ecology: Luzon (the Philippines), elev., ca. $100 \mathrm{~m}$.

Indument pattern: Africana.

Specimens examined: PHILIPPINES. Central Luzon: Prov. Bataam, Mt. Mariveles, $14^{\circ} 32^{\prime} \mathrm{N}$; $120^{\circ} 29^{\prime} \mathrm{E}$, elev., 350 ft, XII/1903, Williams 294 (K).

The materials Cuming 140 (G [ex Herb. Barbey-Boissier], G [ex Herb. Dellesert],) are taxonomically different from the other collections of Cuming 140 (see above). Therefore, they are not considered here as isolectotypes. Such materials correspond to species allied to the Hypolepis punctata and H. tenuifolia (G. Forst.) Bernh. groups, respectively.

11. Hypolepis rugosula (Labill.) J. Sm. subsp. archboldii (Copel.) Schwartsb., stat. nov. for Hypolepis archboldii Copel., Univ. Calif. Publ. Bot. 18(10): 218. 1942. Type: [NEW GUINEA]. [Dutch New Guinea, Mt. Wilhelmina, $7 \mathrm{~km}$ northeast of Wilhelmina-top, elev., $3560 \mathrm{~m}$, subalpine forest, common in ground moss, IX/1938], Brass \& Meyer-Drees 9852 (holotype: MICH-n.v.; isotypes: BM-n.v., FI-PS!, L!0051755, UC [image!]).
Distribution and ecology: New Guinea, elev., ca. $3560 \mathrm{~m}$. Indument pattern: Rufobarbata.

12. Hypolepis rugosula (Labill.) J. Sm. subsp. rugosula, Fig. $1, O$ and $P$.

Hypolepis rugosula (Labill.) J. Sm. var. rugosula C. Chr. \& Skottsb. in Skottsb., Nat. Hist. Juan Fernandez (Botany): 32. 1920, as "var. typica".

Cheilanthes amaurorhachis Kunze, Linnaea 23: 242, 306. 1850. Hypolepis amaurorhachis (Kunze) Hook., Sp. Fil. 2: 62. 1852, as "amaurorachis". Lectotype (designated by Brownsey \& Chinnock 1987: 9): [TASMANIA]. Cultis Hortis Lipsiae ex Tasmania, s.d., Anonymous s.n. [Kunze?] (B!-20 0074521; possible isolectotypes: BR!, K! [ex Herb. Hooker], K! [ex Herb. Kew]).

Hypolepis australis N.A. Wakef., Vict. Naturalist 72: 95. 1955. Type: AUSTRALIA. Eastern Victoria: Arte River, 23 III/1941, Wakefield 107 (holotype: MEL-n.v. [1512588]). Distribution and ecology: Continental Australia (more common on the east coast, but also in the west), Kangaroo Island, King's Island and Tasmania, elev., 600-1500 m.

Indument pattern: Typical.

Representative specimens examined: AUSTRALIA. Queensland: Lamington N.P., elev., 1000 m, V/1977, Parris \& Croxal $6235(\mathrm{~K})$. New South Wales: Blackheath, 33⒊' $150^{\circ} 19^{\prime} \mathrm{E}$, elev., $660 \mathrm{~m}, \mathrm{III} / 1977$, Coveny \& Roy 9190 (K, WELT). Australian Capital Territory: New Chum Road, Cotter Valley, III/1964, Gray 7423 (MBM). Victoria: Peninsula Country Golf Club, near Franstone, $38^{\circ} 08^{\prime}$ S; $145^{\circ} 11^{\prime} \mathrm{E}$, X/1973, Chinnock P781 (K). AUSTRALIA, KANGAROO ISLAND. ca. $4 \mathrm{~km}$ east of Cape Borda, XII/1957, Schodde 528 (K). TASMANIA, KING'S ISLAND. 1802-1805, Brown $16 a$ (K, LE). TASMANIA [VAN DIEMEN'S LAND]. 1833, Gunn s.n. (BR, FI, LE); E of Wedge River, ca. $44 \mathrm{~km} \mathrm{~W}$ of Maydena, $42^{\circ} 43.3^{\prime}$ S; $146^{\circ} 16.3^{\prime} \mathrm{E}$, XII/2007, Brownsey PJBTAS 29 (WELT).

13. Hypolepis rugosula (Labill.) J. Sm. subsp. lactea (Bronswey \& Chinnock) Schwartsb., stat. nov. for Hypolepis lactea Brownsey \& Chinnock, New Zealand J. Bot. 22: 55, figs. 1B, 2A, 3D, 7B, 18B, 19B. 1984. Type: NEW ZEALAND. Wellington: Eastbourne, Butterfly Creek, around fallen log, disturbed ground on creek bank, in beech forest,

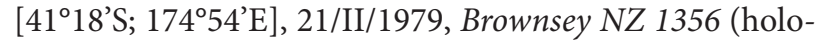
type: WELT! [P11516a]; isotype: CHR-n.v.). Fig. 1, K and L. Distribution and ecology: New Zealand: North, Middle, and South Islands; elev., 150-300 m.

Indument pattern: Lacteal.

Representative specimens examined: NEW ZEALAND, NORTH ISLAND. South Auckland: Kauaeranga Valley, elev., $500 \mathrm{ft}, \mathrm{I} / 1971$, Croxall \& Parris 1479 (K). Rodney County: Kaipara Hills, $36^{\circ} 25^{\prime} \mathrm{S}$; $174^{\circ} 30^{\prime} \mathrm{E}$, elev., $140 \mathrm{~m}$, I/1987, Young s.n. (WELT [P 17888a-c]). Wellington Prov.: East of Masterton, Stronvar, $41^{\circ} 04^{\prime}$ S; $175^{\circ} 56^{\prime} \mathrm{E}$, elev., $300 \mathrm{~m}$, III/2008, Bronwsey s.n. (WELT [P 022219]). NEW ZEA- 
LAND, MIDDLE ISLAND. s.d., Strange s.n. (LE p.p.). NEW ZEALAND, SOUTH ISLAND. Greymouth: 1875-1885, Helms, N.Z.E. 49 p.p. (L-384114). Fiordland: Milford Sound, XII/1989, Smith-Dodsworth s.n. (WELT [P 18047a-b]).

14. Hypolepis rugosula (Labill.) J. Sm. subsp. rufobarbata (Colenso) Schwartsb., comb. nov. et stat. nov. for Polypodium rufobarbatum Colenso, Trans. \& Proc. New Zealand Inst. 16: 347. 1884. Hypolepis rufobarbata (Colenso) N.A. Wakef., Vict. Naturalist 72: 159. 1956. Lectotype (designated by Brownsey \& Chinnock 1984: 54): NEW ZEALAND. Waipawa County, between Norsewood and Danneverke, hills, skirts woods, 1882, Colenso s.n. (WELT! [P3346]; isolectotype: K!). Fig. 1, I and J.

Polypodium viscidum Colenso, Tasm. J. Nat. Sci. 2: 164. 1845 (opus non vidi; cited in Brownsey \& Chinnock 1984) nom. illeg., non Roxburgh (1816). Lectotype (designated by Brownsey \& Chinnock 1984: 52): NEW ZEALAND. Open spots, mountains, near Waikare Lake, XII/1841, Colenso s.n. (WELT-n.v. [P3189]; probable isolectotype: $\mathrm{K}$ ! [“Colenso 269”]).

Distribution and ecology: New Zealand: North, Middle, South, and Stewart Islands; elev., 400-2800 m.

Indument pattern: Rufobarbata.

Representative specimens examined: NEW ZEALAND, NORTH ISLAND. Auckland: 1859, Hochstetter 36 (W). South Auckland: Mt. Pirongia, IV/1966, Bedford s.n., Ex Parris 514 (K). Tongariro National Park: Ohakune, X/1929, Sledge 169 (K). Taupo Co.: 38 57'S; elev., $1180 \mathrm{ft}$, XII/1983, Gardner 4009 (K). Te Aroha: Tawa-Rata forest, elev., 1600 ft, I/1966, Parris 334 (K). Kaukau: Howraki Gulf, XII/1848, Lyell s.n. (K). Taranaki: Mt. Egmont N.P., elev., 2800 m, IV/1966, Parris 475 (K). Upper Hut: Kaitoke Waterworks, II/1979, Brownsey NZ 1359 (WELT); [from Murgaroa Swamp, Upper Hut], cultivated at Orari Gardens, XII/1979, Brownsey NZ 1435 (WELT). Wellington: Akatarawa Saddle, elev., 1400 ft, X/1970, Parris 954 (K). Grey Co.: North of Barrytown, $42^{\circ} 12^{\prime}$ S, s.d., Gardner 4492 (K). NEW ZEALAND, MIDDLE ISLAND. s.d., Strange s.n. (LE p.p.). NEW ZEALAND, SOUTH ISLAND. Westland: Valley of the Teremakau, 1889, Cartwright s.n. (OXF). Canterbury: Banks Peninsula, XII/1961, Melville 5775 (K). Greymouth: 1875-1885, Helms, N.Z.E. 49 p.p. (L-384113, PRC). NEW ZEALAND, STEWART ISLAND. II/1910, Leland et al. 317 (G, K).

15. Hypolepis rugosula (Labill.) J. Sm. subsp. subantarctica (Bronswey \& Chinnock) Schwartsb., stat. nov. for Hypolepis subantarctica Brownsey \& Chinnock, New Zealand J. Bot. 22: 57, figs. 4A, 10, 18C, 19D. 1984. Type: [NEW ZEALAND, CAMPBELL ISLAND]. Cultivated at CHR (G 11407) from Campbell Island, ex Given s.n., 26/III/1981, Brownseys.n. (holotype: WELT!-on 2 sheets [P11518/A and P11518/B]; isotypes: AK-n.v., CHR-n.v.).

Distribution and ecology: New Zealand: Campbell Island and Auckland Island (cited in Brownsey \& Chinnock 1984, no material seen); elevation unknown.

Indument pattern: Typical.

Specimens examined: NEW ZEALAND, CAMPBELL ISLAND. Above Smoothwater Bay, III/1947, Brockie s.n. (WELT [P 7786]).

\section{Final conclusions and future prospects}

From the extant geographic distribution data, it is possible to comprehend how widely distributed Hypolepis rugosula is, as well as to speculate how it was distributed in ancient times. It is also possible to notice the high number of isolated populations around the world (= subspecies richness). There might also be more subspecies, the herbaria material for which was not accessible, especially throughout other oceanic islands and possibly in other places in the Philippines.

Based on the morphological and geographic data alone, the present paper is unique and important in that it aggregates all of the Hypolepis rugosula subspecies names (under the same species-complex) and provides a detailed account of the distribution. The taxonomy proposed here certainly is not final-it is actually the starting point for future works.

Given that we are entering into a collaboration with Drs. Patrick Brownsey and Leon Perrie from the Te Papa Museum of New Zealand, we strongly encourage future works involving molecular investigation and comparison of Hypolepis rugosula subspecies. Such studies should attempt to answer the following questions: Is there one center of origin of $H$. rugosula?; Which were (or are) the routes of migration?; Could the distribution in the Americas, Africa and Oceania be attributable to Gondwana vicariance?; Which matrix areas are involved in long-distance dispersal to oceanic islands, and how many such areas are there?; Do the various indument patterns constitute natural subgroups?; Is it possible to speculate on the age of the species and subspecies, and on why speciation is taking so long?; Does the taxonomy presented here best represent $H$. rugosula?; Are some of the subspecies better classified as species?; and Should varietal level also be incorporated as a third taxonomic level? Cytology will be also very useful to determine which subspecies are tetraploid and which are octoploid. Do they represent two or more consistent and distinct lineages - or are the two ploidies based on random individuals, not representing lineages? Can both occur together in the same isolated population? Are there ploidies other than tetraploid and octoploid?

\section{Dubious names}

Cystopteris elata Desv., Linnaea 6: 264. 1831.-TardieuBlot (1858) considered this to be a synonym of Hypolepis villoso-viscida. We have not analyzed the type of that name. Cystopteris fragilis (L.) Bernh. var. pubescens Phil., Anales Univ. Chile 43: 582. 1873._Rodríguez (1995) synonymized 
this under Hypolepis poeppigii (Kunze) R.A. Rodr. Although we saw the image of the type at Herbarium SGO, we could not be certain of its identity.

Hypolepis juergensii Rosenst., nom. nud. We have not found this name in any publication; nor does any index list it as a 'name validly published. One specimen assigned to this name was analyzed: BRAZIL. Rio Grande do Sul: Sta. Cruz, Linha Chaves, XI/1911, Jürgens 352, Rosenst. Fil. Bras. Exsic. II 77 (B!, NY-n.v.). The specimen at Herbarium B represents H. rugosula subsp. pradoana.

Phegopteris punctata (Thunb.) Mett. var. flaccida Hillebr. in W.F. Hillebr., Fl. Hawaiian Islands (Hillebrand): 563. 1888. Hypolepis flaccida (Hillebr.) W.J. Rob., Bull. Torrey Bot. Club 39: 579. 1912. Lectotype (designated by Brownsey 1987: 271): HAWAII. s.d., Baldwin s.n. (B!-20 0074635).Although this material certainly belongs to $H$. rugosula complex, there is serious doubt as to whether it is really from Hawaii (see Brownsey 1987). Another possibility is that $H$. rugosula could have arrived there but did not establish an effective population.

Polypodium tribrachiatum C. Presl-there is only one exsiccate with this name written by Presl: Cuming 433 (W). This sheet is also an isolectotype of Hypolepis helenensis Fée. Presl's name is probably just a herbarium name; we could not find it validly published anywhere.

\section{Dubious records}

HAWAII-see above in Dubious names.

[SAMOA]. Chatam Island, s.d., Travers s.n. (K, W)-these materials resemble Hypolepis rugosula, showing a pattern of indument similar to the lacteal pattern, but are too poorly preserved to be accurately identified. Dobbie \& Crookes (1951) also recorded H. rugosula from Chatam, but their concept does not totally agree with ours (they listed it also for Japan, for example). Further collections are needed in order to determine whether $H$. rugosula does actually occur in Chatam (possibly as an undescribed subspecies) or not. SOUTH AFRICA-Roux (2001) recorded Hypolepis villoso-viscida from South Africa. Although we saw no material of $H$. rugosula from there, it is likely that it occurs there. Possibly, the best name to apply to this taxon is $H$. rugosula subsp. africana.

[VENEZUELA]. Caracas, s.d., Bredemeyer s.n. (B, W)-these materials clearly belong to the Hypolepis rugosula complex. In the materials at Herbarium W, the locality "Caracas" is overwritten with "St. Helena". According to Schwartsburd (2012a) and Schwartsburd \& Prado (unpublished data), $H$. rugosula does not occur in Venezuela. This collection is most probably from Santa Helena, but since such mislabeling seems so strange, these materials are better left as dubious.

\section{Acknowledgments}

Kley Souza prepared the plant drawings. This work was part of the Doctoral Thesis submitted to the University of São Paulo. P.B.S. thanks CNPq-Brazil for the two Doctoral grants given (at Brazil and for the Sandwich Program abroad); We are grateful to D. Zappi, for the opportunity to develop part of the thesis and manuscript at the Herbarium of the Royal Botanic Gardens, in Surrey, England; to the curators and staff of all of the herbaria visited; to S. Ferreira da Silva, for the support provided; to Kley de Souza, for preparing the illustrations; to the two anonymous reviewers and the editors, for their constructive suggestions; and to I.M. Trotter, for correcting the grammar of the final version of the manuscript.

\section{References}

Agnew, A.D.Q. \& Agnew, S. 1994. Upland Kenya wildflowers - A Flora of the ferns and herbaceous flowering plants of upland Kenya. Nairobi, East Africa Natural History Society, 2nd ed.

Alston, A.H.G. 1959. The ferns and fern-allies of West Tropical Africa, being a supplement to the second edition of the Flora of West Tropical Africa. London, Crown Agents for Oversea Governments and Administrations.

Autrey, J.C.; Bosser, J. \& Ferguson, I.K. 2008. Flore des Mascareignes: La Réunion, Maurice, Rodrigues. Ptéridophytes: 1. Psilotacées à 26. Marsiléacées. Paris, Institut de Recherche pour le Développement.

Bentham, G. \& Mueller, F. von. 1878. Flora Australiensis: a description of the plants of the Australian territory. London, L. Reeve \& Co., vol. VII. Roxburghiaceae to Filices. Reprint by Amsterdam, A. Asher \& Co., and L. Reeve \& Co., Brook Nr. Ashford, 1967.

Brackenridge, W.D. 1854. Botany. Cryptogamia. Filices, including Lycopodiaceae and Hydropterides. United States Exploring Expedition. Botany. Cryptogamia. Filices: 1-357.

Brade, A.C. 1956. A flora do Parque Nacional do Itatiaia. Parque Nacional do Itatiaia, Boletim 5: 7-85.

Brownlie, G. 1957. Cyto-taxonomic studies on New Zealand Pteridaceae. New Phytologist 56: 207-209.

Brownsey, P.J. 1983. Polyploidy and aneuploidy in Hypolepis, and the evolution of the Dennstaedtiales. American Fern Journal 73(3): 97-108.

Brownsey, P.J. 1987. A review of the fern genus Hypolepis (Dennstaedtiaceae) in the Malesian and Pacific regions. Blumea 32(2): 227-276.

Brownsey, P.J. 2001. New Zealand's pteridophyte flora - plants of ancient lineage but recent arrival? Brittonia 53(2): 284-303.

Brownsey, P.J. \& Chinnock, R.J. 1984. A taxonomic revision of the New Zealand species of Hypolepis. New Zealand Journal of Botany 22: 43-80.

Brownsey, P.J. \& Chinnock, R.J. 1987. A taxonomic revision of the Australian species of Hypolepis. Journal of the Adelaide Botanical Garden 10(1): 1-30.

Brownsey, P.J.; Given, D.R. \& Lovis, J.D. 1985. A revised classification of New Zealand Pteridophytes with a synonymic checklist of species. New Zealand Journal of Botany 23: 431-489.

Carmichael, D. 1818. Some account of the Island of Tristan da Cunha and of its natural productions. Transactions of the Linnean Society of London 12(2): 483-513.

Cheeseman, T.F. 1925. Manual of the New Zealand Flora. In: Oliver, W.R.B. (Ed.). Wellington, W.A.G. Skinner, Government Printer, 2nd ed.

Christensen, C. 1906. Index filicum sive enumeratio omnium generum specierumque filicum et hydropteridum ab anno 1753 ad finem anni 1905 descriptorum. Hafniae, H. Hagerup.

Christensen, C. 1920. A monograph of the genus Dryopteris, Part II. The tropical American bipinnate-decompound species. Kongelige Danske Videnskabernes Selskabs Skrifter. Naturvidenskabelige og Mathematiske Afdeling, ser. 8, 6: 3-132.

Christensen, C. 1931 [Feb 1932]. Pteridophyta. In: Perrier, H. (Ed.). Catalogue des plantes de Madagascar. Paris, H.G. Pitot \& Cie., Société d’Éditions Géographiques, Maritimes et Coloniales. 
Christensen, C. 1932. The Pteridophyta of Madagascar. Dansk Botanisk Arkiv Udgivet af Dansk Botanisk Forening 7: 1-253.

Christensen, C. 1934. Index Filicum. Supplementum tertium pro annis 1917-1933. Hafniae, H. Hagerup.

Christensen, C. 1937. Pteridophyta. In: Christophersen, E. (Ed.). Plants of Tristan da Cunha. Scientific Results of the Norwegian Antarctic Expeditions 1927-1928 et sqq., 16: 1-19.

Christensen, C. 1940. The Pteridophytes of Tristan da Cunha. Results of the Norwegian Scientific Expedition to Tristan da Cunha 19371938, 6: 1-25.

Christensen, C. \& Skottsberg, C. 1920. The Pteridophyta of Juan Fernandez Islands. In: Skottsberg, C. (ed.). The Natural history of the Juan Fernandez Islands (Botany). Uppsala, Almqvist \& Wiksells Boktryckeri.

Clifton, R.T.F. 1997. St. Helena: a highly critical Flora. Extract: ferns. Clubmosses included; mosses \& liverworts listed; seaweeds, Algae, Lichens, Fungi not included. The Geraniaceae Group.

Colenso, W. 1883[May 1884]. A further contribution towards making known the Botany of New Zealand. Transactions \& Proceedures of the New Zealand Institute 16: 817-818.

Copeland, E.B. 1942. Filicum novarum CXXVIII diagnosis. University of California Publications in Botany 18(10): 217-226.

Cordemoy, E.J. de. 1891. Flore de l'Ile de La Réunion, fascicule I - cryptogames vasculaires (fougeres, lycopodes, sélaginelles). Paris, Paul Klincksieck.

Cronk, Q.C.B. 1989. The past and present vegetation of St Helena. Journal of Biogeography 16(1): 47-64.

Der, J.P.; Thomson, J.A.; Stratford, J.K. \& Wolf, P.G. 2009. Global chloroplast phylogeny and biogeography of bracken (Pteridium; Dennstaedtiaceae). American Journal of Botany 96(5): 1041-1049.

Diels, L. 1902. Polypodiaceae. In: Diels, L. Eufilicineae. In: Sadebeck, R. Pteridophyta. In: Engler, A. \& Prantl, K. Die natürlichen Pflanzenfamilien nebst ihren Gattungen und wichtigeren Arten insbesondere den Nutzpflanzen, unter Mitwirkung zahlreicher hervorragender Fachgelehrten. Leipzig, Wilhelm Engelmann, I. Teil, Abteilung 4.

Dobbie, H.B. \& Crookes, M. 1951. New Zealand ferns. Whitcombe \& Tombs Ltda., 4th ed.

Domin, K. 1915[1914]. Beiträge zur Flora und Pflanzengeographie Australiens, 1. Lieferung. Bibliotheca Botanica 85: 1-283.

Fée, A.L.A. 1852. Genera filicum. Exposition des genres de la famille des Polypodiacées (classe des fougères) - 5 me Mémoire sur la famille des fougères. Paris, J.B. Baillière; Paris, Victor Masson; Strasbourg, V. Berger-Levraut et fils.

Fée, A.L.A. 1854-1857. Iconographie des espèces nouvelles décrites ou énumérées dans Le genera filicum et révision des publications antérieures relatives a La famille des fougères - $6 \mathrm{me}$, $7 \mathrm{me}$ et $8 \mathrm{me}$ Mémoire sur la famille des fougères. Strasbourg/Paris, Veuve Berger-Levraut et fils; Paris, J.B. Baillière, Victor Masson.

Gay, C. 1853[med. 1854]. Historia física y política de Chile. Botanica. Flora Chilena. Tomo Sexto. Paris, E. Thunot \& Cia.

Groves, E.W. 1981. Vascular plant collections from the Tristán da Cunha group of islands. Bulletin of the British Museum of Natural History (Bot.) 8(4): 333-420.

Haffer, J. 1992. Ciclos de tempo e indicadores de tempos na história da Amazônia. Translated by A. Lamberti. Estudos Avançados 6(15): 7-39.

Hicken, C.M. 1906. Observations sur quelques fougères Argentines nouvelles ou peu connues. Anales de la Sociedad Científica Argentina 62: 14-218.

Hillebrand, W. 1888. In: Hillebrand, W.F. (Ed.). Flora of the Hawaiian Islands: a description of their phanerogams and vascular cryptogams. London, Williams \& Norgate; New York, B. Westermann \& Co.; Heidelberg, Carl Winter Univ. Bookseller.

Hooker, W.J. 1862. Species Filicum; being descriptions of the known ferns, particularly of such as exist in the author's herbarium, or are with sufficient accuracy described in works he has access; accompanied with numerous figures. London, William Pamplin, Vol. IV.

Hooker, W.J. \& Arnott, G.A.W. 1841. The botany of Captain Beechey's voyage; comprising an account of the plants collected by Messrs Lay and Collie, and other officers of the expedition, during the voyage to the Pacific and Bering's Strait, performed in his Majesty's ship
Blossom, under the command of Captain F.W. Beechey, R.N., F.R. \& A.S., in the years 1825, 26, 27, and 28. London, Henry G. Bohn.

Hooker, W.J. \& Baker, J.G. 1868. Synopsis filicum; or, a synopsis of all known ferns, including the Osmundaceae, Schizaeaceae, Marattiaceae, and Ophioglossaceae (chiefly derived from the Kew herbarium). Accompanied by figures representing the essential characters of each genus. London, Robert Hardwicke.

ICBN. 2006. McNeill, J.; Barrie, F.R.; Burdet, H.M.; Demoulin, V.; Hawksworth, D.L.; Marhold, K.; Nicolson, D.H.; Prado, J.; Silva, P.C.; Skog, J.E.; Wiersema, J.H. \& Turland, N.J. (Eds.). International Code of Botanical Nomenclature (Vienna Code). Regnum Vegetabile 146, Liechtenstein, A.R.G. Gantner Verlag KG.

Jenman, G.S. 1881. A hand-list of the Jamaica ferns and their allies. Demerara, Baldwin \& Co's.

Jenman, G.S. 1892. Ferns: synoptical list.-XIII. Bulletin of the Botanical Department of Jamaica 36: 10-11.

Kaulffus, G.F. 1824. Enumeratio filicum quas in itinere circa terram legit Cl. Adalbertus de Chamisso adiectis in omnia harum plantarum genera permultasque species non satis cognitas vel novas animadversionibus. Leipzig, Sumtibus Caroli Cnobloch.

Kornaīs, J. 1979. Distribution and ecology of the pteridophytes in Zambia. Polska Akademia Nauk Wydzial II Nauk Biologicznych.

Kramer, K.U. 1990. Dennstaedtiaceae. Pp. 81-94. In: Kramer, K.U. \& Green, P.S. (Eds.). Pteridophytes and Gymnosperms. In: Kubitzki, K. (Ed.). The families and genera of vascular plants. Berlin, Springer-Verlag.

Kunze, G. 1837. Analecta Pteridographyca seu description et illustratio filicum aut novarum, aut minus cognitarum. Lipsiae, Imprensis Leopoldi Voss.

Kunze, G. 1848. In filices Javae Zollingerianas observationes (continuatae). Botanische Zeitung. Berlin 6(11): 209-216.

Kunze, G. 1850. Index Filicum (sensu latissimo) adhuc, quantum innotuit, in hortis Europaeis cultarum, cum synonymis gravioribus, patria, introductionis s. germinationis tempore, duratione et cultura. Linnaea 23(2): 242-306.

Labillardière, J.J. 1800. Voyage in search of La Pérouse. Performed by order of The Constituent Assembly, during the years 1791, 1792, 1793, and 1794. Translated from the French into English. London, John Stockdale, vol. I.

Labillardière, J.J. 1802. An account of a voyage in search of La Pérouse, undertaken by order of the Constituent Assembly of France, and performed in the years 1791, 1792, and 1793, in the Recherche and Esperance, ships of war, under the command of Rear-Admiral Bruni d'Entrecasteaux. Translated from French into English. London, B. Uphill, vol. II, 2nd ed.

Labillardière, J.J. 1806. Novae Hollandiae plantarum specimen. vol. II, Paris, Huzard.

Lellinger, D.B. 1977. Nomenclatural and taxonomic notes on the pteridophytes of Costa Rica, Panama, and Colombia, I. Proceedings of the Biological Society of Washington 89(61): 703-732.

Manton, I. \& Vida, G. 1968. Cytology of the fern flora of Tristan da Cunha. Proceedings of the Royal Society (London, Biol. Sci.) 170: 361-379.

Mettenius, G. 1858. Über einige Farngattungen, IV. Phegopteris und Aspidium. Frankfurt, Druck und Verlag von Heinrich Ludwig Brönner.

Mettenius, G. 1865. Aspidiaceae. In: Ettingshaussen, C.R. von. Pp. 159-166. Die Farnkräuter der Jetztwelt zur untersuchung und bestimmung der in den formationen der erdrinde eingeschlossenen überreste von vorweltlichen arten dieser ordnung nach dem flächen-skelet bearbeitet. Wien, Verlag von Carl Gerold's Sohn.

Meurk, C.D.; Foggo, M.N. \& Wilson, J.B. 1994. The vegetation of Subantarctic Campbell Island. New Zealand Journal of Ecology 18(2): 123-168.

Mickel, J.T. \& Smith, A.R. 2004. The Pteridophytes of Mexico. Memoirs of the New York Botanical Garden 88: 1-1055.

Moore, T. 1857-1862 [1857]. Index Filicum: a synopsis, with characters, of the genera, and an enumeration of the species of ferns, with synonymies, references, etc., etc. London, Willian Pamplin.

Moran, R.C. 1995. Hypolepis Bernh. In: Moran, R.C. \& Riba, R. (Eds.). Psilotaceae a Salviniaceae. Pp. 153-157. In: Davidse, G., Sousa, M. \& Knapp, S. (Eds.). Flora Mesoamericana. Ciudad de México, Universidad Nacional Autónoma de México, vol. 1. 
Moran, R.C. 2008. Diversity, biogeography, and floristics. Pp. 367-394. In: Ranker, T.A. \& Haufler, C.H. (Eds.). Biology and evolution of ferns and lycophytes. Cambridge, Cambridge University Press.

Papavero, N.; Teixeira, D.M. \& Prado, L.R. 2013. História da biogeografia - do Gênesis à primeira metade do Século XIX. Rio de Janeiro, Technical Books Ed.

Parris, B.S. 2001. Circum-Antarctic continental distribution patterns in pteridophyte species. Brittonia 53(2): 270-283.

Petit-Thouars, A. du. 1808. Esquisse de la flore de Tristan d'Acugna, ou Catalogue des plantes trouvées dans cette isle, dans les premiers jours de janvier 1793, précédée d'une description abrégée des isles dont elle fait partie. Paris.

Petit-Thouars, A. du. 1811. Mélange de Botanique et de voyages. Paris, Chez Arthus Bertrand, premier recueil.

Philippi, F. 1881. Catalogus plantarum vascularium Chilensium adhuc descriptarum. Santiago de Chile, Imprenta Nacional.

Pichi-Sermolli, R.E.G. 1983. A contribution to the knowledge of the Pteridophyta of Rwanda, Burundi, and Kivu (Zaire) - I. Bulletin du Jardin Botanique National de Belgique 53: 177-284.

Pizarro, C.M. 1959. Sinopsis de La Flora Chilena. Santiago, Editorial Universitaria S.A.

Ponce, M.; Prado, J. \& Sota, E.R. de la. 2008. Dennstaedtiaceae. In: Zuloaga, F.; Morrone, O. \& Belgrano, M. (eds.). Catálogo de las plantas vasculares del Cono Sur. Monographs in Systematic Botany from the Missouri Botanical Garden 107(1): 26-31.

Proctor, G.R. 1985. Ferns of Jamaica - A Guide to the pteridophytes. London, British Museum (Natural History), Henry Ling Ltd.; Dorchester, The Dorset Press.

Rawlings, G.B. 1974. Northland notes 3. New Zealand Journal of Botany 12: 563-565.

Reimers, H. 1934. Pteridophyta V. In: Mildbraed, J. Neue und seltene Arten aus Ostafrika (Tanganyica-Territ. Mandat) leg. H.J. Schlieben, VII. Notizblatt des Botanischen Gartens und Museums zu Berlin-Dahlem 112(12): 188-191.

Rodríguez, R. 1995. Parte descriptiva - Pteridophyta. Pp. 119-309. In: Marticorena, C. \& Rodríguez, R. (eds.). Flora de Chile, vol. 1, Pteridophyta - Gymnospermae. Concepción, Universidad de Concepción.

Roux, J.P. 2001. Dennstaedtiaceae-Pteropsida: Hypolepis villoso-viscida new to the Flora of Southern Africa. Bothalia 31(2): 195.

Roux, J.P. 2009. Synopsis of the Lycopodiophyta and Pteridophyta of Africa, Madagascar and neighbouring islands. Strelitzia 23. Pretoria: South African National Biodiversity Institute.

Roxburgh, W. 1816. An alphabetical list of plants, seen by Dr. Roxburgh growing on the Island of St. Helena, in 1813-14. Pp. 295-326. In: Beatson, A. (Ed.). Tracts relative to the Island of St. Helena; written during a residence of five years. London: W. Bulmer \& Co. Cleveland-Row.

Schelpe, E.A.C.L.E. 1970. Pteridophyta. In: Exell, A.W. \& Launert, E. (eds.). Flora Zambesiaca - Mozambique, Malawi, Zambia, Rhodesia, Botswana. London, Crown Agents for Oversea Governments and Administrations.

Schwartsburd, P.B. 2010. Dennstaedtiaceae. Pp. 530-531. In: Forzza, R.C.; Leitman, P.M.; Costa, A.; Carvalho Jr., A.A. de; Peixoto, A.L.; Walter, B.M.T.; Bicudo, C.; Zappi, D.; Costa, D.P. da; Lleras, E.; Martinelli, G.; Lima, H.C. de; Prado, J.; Stehmann, J.R.; Baumgratz, J.F.A.; Pirani, J.R.; Sylvestre, L.S.; Maia, L.C.; Lohmann, L.G.; Paganucci, L.; Silveira, M.; Nadruz, M.; Mamede, M.C.H.; Bastos, M.N.C.; Morim, M.P.; Barbosa, M.R.; Menezes, M.; Hopkins, M.; Secco, R.; Cavalcanti, T. \& Souza, V.C. (orgs.). Catálogo de plantas e fungos do Brasil. Rio de Janeiro, Jardim Botânico do Rio de Janeiro, vol. 1.
Schwartsburd, P.B. 2012a. O gênero Hypolepis Bernh. (Dennstaedtiaceae) na América do Sul. Doctoral Thesis, Universidade de São Paulo, São Paulo.

Schwartsburd, P.B. 2012b. Three new taxa of Hypolepis (Dennstaedtiaceae) from the Brazilian Atlantic Forest, and a key to the Brazilian taxa. Kew Bulletin 67(4): 815-825.

Schwartsburd, P.B. \& Prado, J. 2011. Typification of Polypodium rugosulum Labill. (= Hypolepis rugosula, Dennstaedtiaceae), a new subspecies, and a new status for one variety. Webbia 66(2): 155-163.

Serbert, R. \& Rothwell, G.W. 2003. Anatomically preserved ferns from the Late Cretaceous of western North America: Dennstaedtiaceae. International Journal of Plant Sciences 164: 1041-1051.

Skottsberg, C. 1920-1956. Derivation of the Flora and Fauna of Juan Fernandez and Eastern Islands. Pp. 193-438. In: Skottsberg, C. (Ed.). The Natural History of Juan Fernandez and Eastern Island. Uppsala, Almqvist \& Wiksells Boktryckery, vol. 1.

Skottsberg, C. 1935. Notes on the vegetation in the Cumberland Bay caves, Masartierra, Juan Fernandez Islands. Ecology 16(3): 364-374.

Smith, A.R. \& Mickel, J.T. 1977. Chromosome counts for Mexican ferns. Brittonia 29: 391-398.

Smith, A.R.; Pryer, K.M.; Schuettpelz, E.; Korall, P.; Schneider, H. \& Wolf, P.G. 2008. Fern classification. Pp. 417-467. In: Ranker, T.A. \& Haufler, C.H. (Eds.). Biology and evolution of ferns and lycophytes. Cambridge, Cambridge University Press.

Stafleu, F.A. \& Cowan, R.S. 1979. Taxonomic Literature - a selective guide to botanical publications and collections with dates, commentaries and types. Vol. II: H-Le. Utrecht, Bohn, Scheltema \& Holkema, The Hague, 2nd ed.

Tardieu-Blot, M. 1958. 5e Famille - Polypodiacées (sensu lato) (5.1 Dennstaedtiacées - 5.10 Aspidiacées). In: Humbert, H. (Ed.). Flora of Madagascar 1: 1-391.

Thomson, J.A. 2012. Taxonomic status of diploid southern hemisphere brackens (Pteridium: Dennstaedtiaceae). Telopea 14: 43-48.

Tryon, R.M. 1941. A revision of the genus Pteridium. Rhodora 43: 1-67.

Tryon, R.M. 1970. Development and evolution of fern floras of oceanic islands. Biotropica 2: 76-84.

Tryon, R.M. \& Tryon, A.F. 1982. Ferns and allied plants, with special reference to Tropical America. New York, Springer-Verlag.

Underwood, L.M. \& Maxon, W.R. 1930. In: Maxon, W.R. Fern miscellany. Procedures of the Biological Society of Washington 43: 81-88.

van Alderwerelt van Rosenburgh, C.R.W.K. 1908. Malayan ferns - handbook to the determination of the ferns of the Malayan Islands (incl. those of the Malay Peninsula, the Philippines, and New Guinea). Landsdrukkerij, The Department of Agriculture, Industry and Commerce Netherlands India.

Velayos, M.; Aedo, C.; Cabezas, F. \& Estrella, M. de la. 2008. Flora de Guinea Ecuatorial - Claves de plantas vasculares de Annobón, Bioko y Río Muni. Madrid, Consejo Superior de Investigaciones Científicas, vol. 1-Psilotaceae a Vittariaceae.

Verdcourt, B. 2000. Dennstaedtiaceae. In: Beentje, H.J. \& Smith, S.A.L. (Eds.). Flora of Tropica East Africa. Surrey, Royal Botanic Gardens, Kew; A.A. Balkema/Rotterdam/Brookfield.

Wakefield, N.A. 1955. Flora of Victoria: new species and other additions - 5. Victorian Naturalist 72(6): 92-95.

Wakefield, N.A. 1956. New combinations in some Australasian ferns - 2. Victorian Naturalist 72(10): 159-160.

Wolf, P.G.; Schneider, H. \& Ranker, T.A. 2001. Geographic distribution of homosporous ferns: does dispersal obscure evidence of vicariance? Journal of Biogeography 28: 263-270. 
APPENDIX 1 - Full examined material

Below is the totality of the specimens examined in this work. Coordinates inside square brackets were estimated.

1. Hypolepis rugosula subsp. pulcherrima (L.M. Underw. \& Maxon) Schwartsb. \& J. Prado. Lectotype: JAMAICA. Blue Mt. Range, $\left[18.0392^{\circ} ;-76.5741^{\circ}\right]$ elev., 7000 ft, VII/1878, G.S. Jenman 72 (K!).

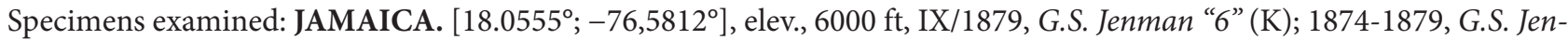
man s.n. (OXF [00072087]); Blue Mt. Peak, III/1885, D. Morris 100 (BM); 17/VII/1897, O. Hansen 28 (B); 1897, O. Hansen s.n. (BM); Sir John's Peak, $\left[18.1230^{\circ} ;-76.6548^{\circ}\right], 9 / \mathrm{IV} / 1910$, M.D. Watt 6 (K, U); west slope of the Blue Mountain Peak, elev., $6500 \mathrm{ft}, 08 / \mathrm{X} / 1952$, G.R. Proctor 7222 (U); St. Andrew, south of the grand ridge of the Blue Mountains, small tributary headwaters of the Clyde River, $18^{\circ} 05^{\prime} \mathrm{N}$; 76³9'W, elev., ca. 1580 m, 18/IV/1990, P.J. Bellingham 1168 (BM-on 2 sheets); Parish of Portland, west of Sir John Peak on the grand ridge of the Blue Mountains, steep ridge hanks at headwaters of the Mabess River, $18^{\circ} 05^{\prime} \mathrm{N} ; 7^{\circ} 38 \mathrm{~W}$, elev., ca. $1680 \mathrm{~m}, 10 / \mathrm{VI} / 1990$, P.J. Bellingham 1262 (BM); Parish of Portland, northwest of Sir John Peak, headwaters catchment of the Mabess River, $18^{\circ} 05^{\prime} \mathrm{N}$; $76^{\circ} 38 \mathrm{~W}$, elev., ca. $1740 \mathrm{~m}, 26 / \mathrm{IV} / 1991$, P.J. Bellingham 1433 (BM); Parish of St. Thomas, north of the grand ridge of Blue Mountains, immediately northwest of Portland Gap, $18^{\circ} 02^{\prime} \mathrm{N} ; 76^{\circ} 36^{\prime} \mathrm{W}$, elev., ca. $1680 \mathrm{~m}, 03 / \mathrm{VII} / 1991$, P.J. Bellingham 1536 (BM-on 2 sheets); Summit of the Blue Mountain Peak, elev., 2100-2200 m, 7-9/VII/1926, W.R. Maxon 9912 (US-on 4 sheets [image!] - previous lectotype of H. pulcherrima).

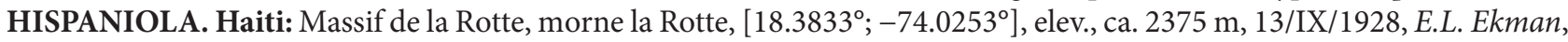
Pl. Ind. Occid. H 10636 (BM).

2. Hypolepis rugosula subsp. colorata (H. Christ) Schwartsb. \& J. Prado. Lectotype: COSTA RICA. Forêts au dessus de l'Achiote, au volcan de Poás, [10.2003º $-84.2000^{\circ}$ ], elev., 2000 [-2200] m, XI/1896, A. Tonduz 10704 (BR!; isolectotypes: G!-2 sheets [ex Herb. Boissier], G! [ex Herb. Dellesert], LE! [ex Herb. Inst. Phys.-Geogr. C.R.], LE! [ex Herb. Pittier \& Durand], LE! [ex Herb. Tonduz], P-n.v.).

Specimens examined: COSTA RICA. Alto del Sacatal, versant E du massif de Buena Vista, $\left[10.1798^{\circ} ;-84.2362^{\circ}\right]$, elev., 2500 m, I/1897, Pittier 10529 (BR!, P-2 sheets-n.v.-syntypes of H. repens var. colorata); Forêts du Roble, massif du Volcan Irazu, [9.9938 ; $-83.8773^{\circ}$ ], elev., 2000 m, 10/VII/1891, A. Tonduz 4173 bis (BR); Volcan Poas, Prov. Alajuela, elev., 2300 m, III/1896, J.D. Smith 6861 (B, G, K).

3. Hypolepis rugosula subsp. poeppigiana (Mett.) Schwartsb. \& J. Prado. Lectotype: CHILE. [Los Ríos]: prope coloniam Arique in prov. Valdivia, [-39.8985 $;-73.2394^{\circ}$ ], V/1851, W. Lechler, Pl. Chil. 194 (B!-20 0074790 [ex Herb. Mettenius]; isolectotypes: B!-20 0074789 [ex Herb Mettenius], B!-20 0074791, FI!, FI-W!-214914, G!-on 2 sheets, GOET-n.v., K!000640324, K!-000640325, K!-000640326, L!, LE!, LE! [ex Herb. Petropol.], UPS!, W!).

Hypolepis chilensis Fée. Syntypes: CHILE. [Valparaíso]: Valparaiso, [1834 or 1835], C. Gaudichaud s.n. [31?] (BR!, FI-W!214906, FI-W!-214910, FI-W!-216216, G!, RB!, W!; probable duplicate: FI-W!-214917). CHILE. San Juan Fernandez: C. Gay (P?-n.v., PC?-n.v.). CHILE. [Los Ríos]: près de la colonie Arique, province de Valdivia, [V/1851],W. Lechler [Pl. Chil. 194] (B!-3 sheets [20 0074789, 20 0074790, 20 0074791], FI!, FI-W!-214914, G!-on 2 sheets, GOET-n.v., K!000640324, K!-000640325, K!-000640326, L!, LE!, LE! [ex Herb. Petropol.], UPS!, W!).

Phegopteris poeppigii var. hirsuta Phil. Lectotype: [CHILE]. Puerto Lagunas, I/1872, E. Simpson s.n. (SGO-000000467 [image!]).

Hypolepis hauman-merckii Hicken. Lectotype: ARGENTINA. Prov. Buenos Aires: Sierra de la Ventana, [-38.1625; -61.5912²], 25/XII/1905, M. Hauman-Merck s.n. (SI-000095 [image!]).

Specimens examined: ARGENTINA. Buenos Aires: Celle du Tandil, s.d., M. Hauman-Merck (SI?-n.v. - syntype of Hypolepis hauman-merckii). Neuquén: Correntoso, $\left[-38.9872^{\circ}\right.$; $\left.-68.0025^{\circ}\right], 10 / \mathrm{I} / 1935$, A.L. Cabrera \& M.M. Job 227 (LP); Brazo Rincón, [-40.7352 $;-71.7422^{\circ}$ ], XI/1985, B. Polastry s.n. (BCRU); [Villa la Angostura?], Quetrihué, [ $-40.7555^{\circ} ;-71.6434^{\circ}$ ], 06/VI/1943, J. Diem 728 (SI). Rio Negro: Puerto Blest, picada a Pto. Cántaros, [-41.0289; $\left.-71.8153^{\circ}\right], 29 / X I / 1997, J$. Puntieri 396 (BCRU-on 2 sheets); Puerto Blest, picada a Pto. Cántaros, 29/XI/1997, J. Chiapella \& J. Puntieri s.n. (BCRU). CHILE. Coquimbo: Bosque Fray Jorge, $\left[-30.0312^{\circ}\right.$; $\left.-71.3262^{\circ}\right]$, elev., $500 \mathrm{~m}, 07 / \mathrm{VII} / 1938$, C.H. Andreas 856 (L-on 2 sheets, U); Bosque de Talinay, [-30.0040 $\left.{ }^{\circ} ;-71.1607^{\circ}\right], 08 / \mathrm{II} / 1948$, C. Jiles 576 (SI). Valparaíso: Valparaiso, $\left[-33.1538^{\circ} ;-71.5462^{\circ}\right]$, s.d., Anonymous [unreadable, “Bredger"?] 562 (W). Bío-Bío: Prope Conception, [-36.9080 ; $\left.-73.0088^{\circ}\right], 1832, \mathrm{H}$. Cuming 149 (BM); Concepción, Southern Chili [Chile], [-36.7792 ; $\left.-72.9187^{\circ}\right]$, s.d., R.A. Philippi s.n. (K); ad Portum Coronel, $\left[-37.0198^{\circ} ;-73.0883^{\circ}\right], 1866$, "Buehenau" s.n., ex Herb. Martii (BR-on 2 sheets). La Araucanía: Tolten forest, [-39.1714 ; 
$-72.8980^{\circ}$ ], 10/I/1902, H.J. Elwes s.n. (K); Telmuco [Temuco?], Malquehue, [-38.8019 $\left.{ }^{\circ} ;-72.5104^{\circ}\right], \mathrm{I} / 1905$, Anonymous [R.M. Middleton?] s.n., ex Herb. Middleton (G); Prov. Cautín, Telmuco, Cierro Nielol, 3843's; $72^{\circ} 35^{\prime}$ W, elev., 150 m, 15/ VII/1939, G. Montero 3696 (G-on 2 sheets). Los Ríos: Valdívia, [-39.8288 $\left.;-73.1161^{\circ}\right]$, Anonymous s.n., ex Herb. Reed (K); circa Valdivia, s.d., Brudgel \& Osorio 813 (FI-W); Valdivia, [-39.8961 ${ }^{\circ}$; $73.0784^{\circ}$ ], s.d., Krause s.n., ex Herb. Fil. Christensen

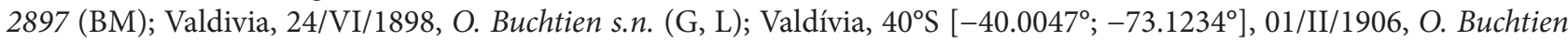
s.n. (B ['084677']); near Arique, 7 leagues above Valdívia, Anonymous 813 (K); Prov. Valdivia, "Pauquipulei”, [-39.9440; $-73.5471^{\circ}$ ], elev., ca. 200 m, V/1926, A. Hollermayer s.n., Werdermann Pl. Chilensis n. 1880 (B-n.v., U); Prov. Valdivia,

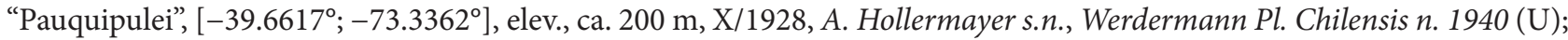
(as "X Región"), Prov. Valdivia, Camino de Corral a Amargos, 01/II/1935, C.C. Hosseus 113 (CORD); Prov. Valdivia, Chaiguín, Corral, 3957’S; 73³0’W, elev., 100 m, 19/XII/1953, [B.?] Sparre \& [?] Smith 280 (G); Valdivia, s.d., Anonymous s.n. (SI-22740). Los Lagos: Puerto Varas, $\left[-41.3394^{\circ} ;-72.8580^{\circ}\right], 26 / \mathrm{I} / 1929$, C.M. Hicken 51 (SI); Puerto Montt, [-41.4721 ${ }^{\circ}$; $-72.7735^{\circ}$ ], s.d., [R.A. or F.?] Philippi s.n. (K); Puerto Montt, Anonymous, ex Herb. Reed (LE-on 2 sheets?); Prov. Llanquihue, Puerto Montt, Contao, Camino al Sur, [-41.3596 ; $\left.-72.5720^{\circ}\right], 12 / \mathrm{I} / 1981$, G. Montero 12011 (G); Prov. Llanquihue, Dpto. Puerto Vargas, Volcán Osorno, 41¹0’S; 72³0’W, elev., 500 m, 19/I/1971, E. Weldt \& R. Rodríguez 826/121 (G-on 2 sheets); as "Prov. Chiloé", Llanquihue, road from Hotel Ensenada to Cochamo and Laguna Patos, elev., 75 m, 21/III/1939, J.L. Morrison 17569 (G, K); Santa Lucia, sur le Carretera "Austral”, à $81 \mathrm{~km}$ de Chaiten, [ $-43.3409^{\circ}$; $\left.-72.3585^{\circ}\right]$, elev., $200 \mathrm{~m}$,

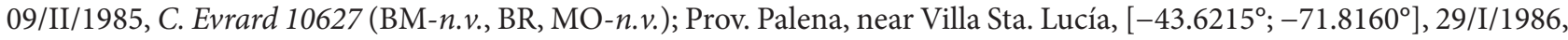
T.M. Pedersen 14329 (BR, MBM). Aysén del General Carlos Ibañez del Campo: Aysén, [-45.2868 ; $\left.-72.8575^{\circ}\right], 11 / \mathrm{II} / 1959$, Anonymous [Kunkel?] n. 2963 (G [as "f. patagonica"-type?]); Aysén, Pto. Aysén, 11/II/1959, Anonymous [unreadable] n. 2692 (G-on 2 sheets); Prov. Aysén, Fjord Quitralco, 4543’3; 73²5’W, 01/XII/1987, K.H. Rechinger \& W. Rechinger 63988

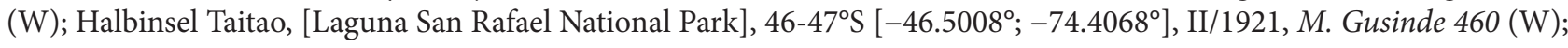
Patagonia Occid., Golfo de Peñas, Pto. Hale, [-46.5632 ${ }^{\circ}$; $\left.75.2995^{\circ}\right]$, 09/VI/1908, C. Skottsberg 302 (UPS). Magallanes

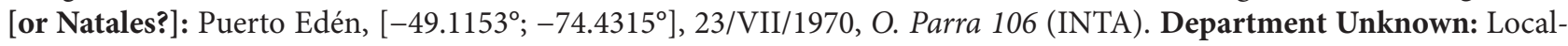
ity unknown, Philippi s.n. (BM); Locality unknown, Philippi "3" (BM, G, K); Locality unknown, H. Cuming s.n. (OXF [as "Cumming"]); Locality unknown, 1833, Anonymous [unreadable] s.n. (K); Locality unknown, 1870, Shazmann s.n. (G); Locality unknown, Anonymous s.n. (W ['364981']); South Chile, VIII/1919(?), Anonymous [unreadable, "Escherholz"?] s.n. (LE, LECB); San Rafael, elev., 150 m, 16/II/1921, F. Reichert s.n. (SI-2 sheets [ex Herb. Hicken 33 [as “16/III/1921”] et 34]); Melinka, elev., 20 m, 27/I/1938, C.H. Andreas 473 (U).

CHILE, JUAN FERNÁNDEZ ISLANDS. Más a Tierra [Robinson Crusoe]: $\left[-33.6565^{\circ} ;-78.7996^{\circ} /-33.6298^{\circ}\right.$; $-78.8664^{\circ} /-33.6515^{\circ} ;-78.8898^{\circ}$ ], Valle Colonial, 11/XII/1916, C. Skottsberg \& I. Skottsberg 120 (K, UPS); Kolonidalen, 03/ IV/1917, C. Skottsberg \& I. Skottsberg 587 (UPS); Cumberland Bay, San Juan Bautista, in one of the Spanish Caves, at the Settlement, 13/XII/1965, F.G. Meyer 9536 (K, LP, NA-n.v.); Grutas de los Patriotas, 10-25/II/1955, B. Sparre 14 (K); San Juan

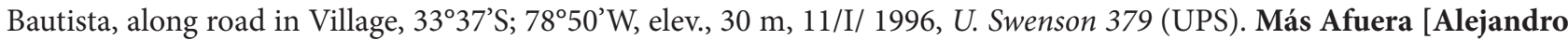
Selkirk]: Quebrada del Mono, [-33.7612 ; $-80.7694^{\circ}$ ], elev., ca. 400 m, 12/II/1917, C. Skottsberg \& I. Skottsberg 439 (UPS). Island Unknown: "In sylvatica ad rivulorum marginae collinae", IV/1830 [or V/1830], M. Bertero 1664 (G-2 sheets, K-3 sheets); Anonymous [Bertero?] 1348 (K); M. Bertero s.n. (G-on sheets).

CHILE, CHILOÉ ISLANDS. Chiloé [Isla Grande de Chiloé]: [ $-42.9494^{\circ} ;-73.8340^{\circ}$ ], s.d., Cap. King s.n. (K-on 2 sheets); 1830, R. Brown(?) s.n. (BM); 08/IV/1868, R.O. Cunningham 26 (K); "Yenam", 18/V/1868, Anonymous [probably Cunningham] s.n. (K [same sheet as Cunningham 26]); Castro [Dalcahue], Piruquina, [-42.3668 ; $-73.7887^{\circ}$ ], elev., $200 \mathrm{~m}$, III/1924, E. Werdermann, Pl. Chilensis n. 304 (G, SI, U); [Dalcahue], "Tiruquina” [Piruquina], [-42.3220 ${ }^{\circ} ;-73.8470^{\circ}$ ], 04/X/1931, C. Junge 32 (MO-n.v., PRC, SI); [Dalcahue], Piruquina, 04/X/1931, C. Junge 40 (L); 20/II/1971, O. Zöllner 4779 (L).

ARGENTINA or CHILE. Department Unknown: Patagonia, ['-41.6050 ; $-68.8782^{\circ}$ ] , F. Steindachner s.n. (W ['9293']); Puerto Leopoldo, II/1921, Hicken s.n. (SI [ex Herb. Hicken 35]); Locality unknown, 22/I/1909, P. "Nurett"(?) 53 (SI).

4. Hypolepis rugosula subsp. pradoana Schwartsb. Type: BRAZIL. Rio de Janeiro: Teresópolis, Parque Nacional da Serra dos Órgãos, Matas Nebulares e Campos de Altitude, Pedra do Sino, próximo ao Abrigo Quatro, no caminho para a caixa

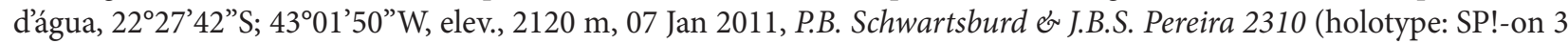
sheets; isotypes: B!, FI!, G!, K!-on 3 sheets, LP!, NY!-on 2 sheets, P!-on 2 sheets, PRC!, RB!-on 2 sheets, SI!, SP!, UC!, UPCB!, VIC!, WELT!).

Specimens examined: BRAZIL. Minas Gerais: Alto Caparaó, Parque Nacional do Caparaó, Pico da Bandeira, [20 $26^{\circ}$ '

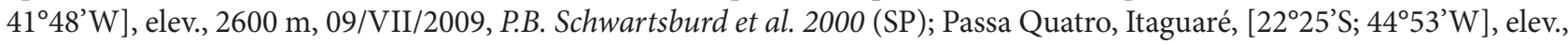
2000 m, 09/V/1948, A.C. Brade \& S. Araújo 19100 (RB); Locality unknown, Anonymous [T. de Moura?] 59, ex Herb. Moura

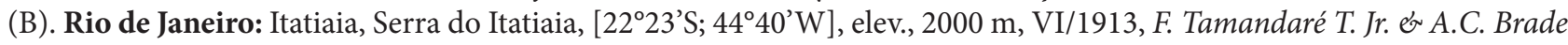
'839' vel '1837' (RB); Itatiaia, Serra do Itatiaia, elev., 2000 m, 4-10/VI/1913, F. Tamandaré T. Jr. \& A.C. Brade 6501 (HB, 


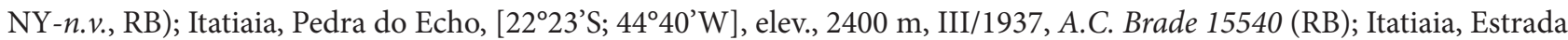

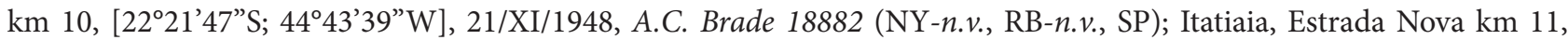

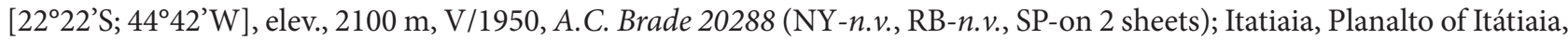

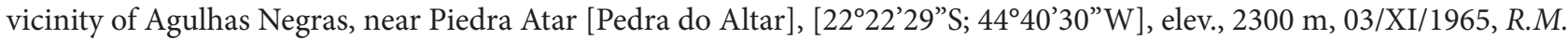
Tryon \& A.F. Tryon 6682 (GH-n.v. HB); Itatiaia, Planalto of Itátiaia, vicinity of Agulhas Negras, near Piedra Atar [Pedra do Altar], elev., 2300 m, 03/XI/1965, R.M. Tryon \& A.F. Tryon 6683 (GH-n.v., HB); Itatiaia, Parque Nacional do Itatiaia,

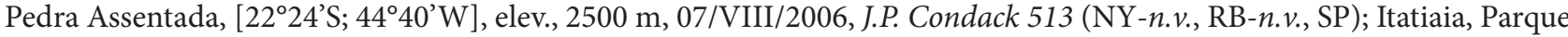

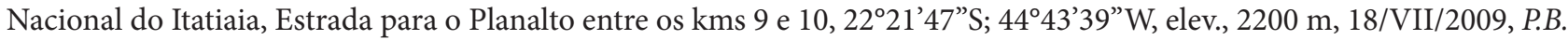
Schwartsburd et al. 2197 (SP); Nova Friburgo, Pico da Caledônea, 22²1'13”S; 42³5'13", elev., 2220 m, 15/VI/2004, R.C. Forzza et al. 3412 (RB-n.v., SP-2 sheets, SPF); Petrópolis, Parque Nacional da Serra dos Órgãos, Castelo do Açu, 22 29’08"S; 4303’42”W, elev., 2100-2150 m, 10/I/2011, P.B. Schwartsburd et al. 2323 (SP); Therezopolis [Teresópolis], 11/III/1938(?), A.C. Brade s.n., ex Herb. Mus. Nac. Rio Janeiro 21047 (BM-on 2 sheets, R-n.v.). Paraná: Campina Grande do Sul, Parque Estadual do Pico do Paraná, 2515’S; 4850'W, elev., 1500-1876 m, 09/VII/2008, P.H. Labiak et al. 4778 (UPCB-on 2 sheets).

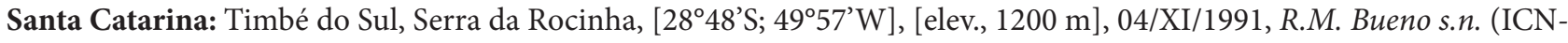
155000). Rio Grande do Sul: Santa Cruz, $\left[-30.1847^{\circ} ;-54.2575^{\circ}\right]$, XI/1911, C. Jürgens 352, Rosenst. Fil. Austrobras. exsic. II 77 (B, NY-n.v.-type of Hypolepis juergensii Rosenst.?).

5. Hypolepis rugosula subsp. villoso-viscida (Thouars) Schwartsb. \& J. Prado. Type: TRISTAN DA CUNHA. A. du PetitThouars s.n. (P-00522442 [image!]).

Cheilanthes viscosa Carmich. Syntypes: Island of Tristan da Cunha, in the Wood, D. Carmichael s.n. (BM!, K! [000369140]).

Specimens examined: TRISTAN DA CUNHA. Above Sandy Point, [-37.0897; $\left.-12.3192^{\circ}\right]$, elev., $200 \mathrm{~m}, 18 / \mathrm{I} / 1938, Y$. Mejland 1158 (K, L); 1924, [-37.1065, -12.2309º , H.M. Rogers s.n. (K [000369143]).

INACCESSIBLE ISLAND. Central part of plateau, tree fern country, [-37.3017 ; $\left.-12.6789^{\circ}\right]$, elev., $400 \mathrm{~m}, 25 / \mathrm{II} / 1938, E$. Christophersen 2498 (BM-n.v., K, O-n.v.).

NIGHTINGALE ISLANDS. Trail to lake region, cliff in tussock grass, [ $\left.-37.4220^{\circ} ;-12.4798^{\circ}\right]$, elev., $100 \mathrm{~m}, 12 / \mathrm{II} / 1938, E$. Christophersen 2233 (BM-n.v., K, O-n.v.); west ridge to peak, moist cliff, [-37.4245 ; $-12.4828^{\circ}$ ], elev., 200 m, 10/II/1938, E. Christophersen 2224 (K); in a cave, 1924, H.M. Rogers s.n. (K [000369141]).

GOUGH ISLAND. Slope above Glen Creek, 100 yds from Archway Rock, [-40.3595º; $\left.-9.9033^{\circ}\right]$, elev., 40 ft, 05/XII/1955, N.M. Wace 30 (BM); Slope above Lower Watersmeet, main Glen, 02/II/1956, N.M. Wace 128 (BM); creek banks on southern aspect of Tafel Koppie, $40^{\circ} \mathrm{S} ; 09^{\circ} \mathrm{W},\left[-40.2919^{\circ}\right.$; $\left.-9.9430^{\circ}\right]$, elev., $270 \mathrm{~m}, 03 / \mathrm{XI} / 1979$, J.P. Roux 745 (K).

6. Hypolepis rugosula subsp. viscida (Roxb.) Schwartsb. \& J. Prado. Lectotype: SAINT HELENA. Sandy Bay, about stone dikes, 1813-1814, J. Roxburgh 191/1 (BM!).

Cheilanthes remota Kunze. Type: SANTA HELENA. C. W. Petersen (herb.?; possible type: BR! [Anonymous, ex Herb. Martii]). Hypolepis helenensis Fée. Lectotype: [SAINT HELENA]. Habitat in Insulâ Sanctae Helenae, [1841], H. Cuming 433 (RB! [215823]; isolectotypes: B! [20 0075256], B! [20 0075263], B! [20 0075264], B! [20 0075265], B! [20 0075268], BM!, G!-2 sheets [ex Herb. Barbey-Boissier], G! [ex Herb. de Candolle], G! (ex Herb. Delessert), G! [ex Herb. Moricand], K! [000214965], K!-on 2 sheets [000350990 and 000350991], L! [0051757], L! [0051758], LE!-2 sheets [ex Herb. Fischer], LE! [ex Herb. Petropol.], OXF!, UPS!, W! [ex Herb. Palat. Vindob], W! [ex Herb. Presl]).

Specimens examined: SAINT HELENA. Valley near the Willow Point, XII/1809, Burchell 191 (B, K-2 sheets); Diana's Peak, $\left[-15.9638^{\circ} ;-5.7116^{\circ}\right]$, VII/1813, J. Roxburgh 23 (BM-syntype of Polypodium viscidum?); 1832, Lesson s.n. (K [000214957]); 1860-1871, [-15.9282 ; -5.6975], elev., $2000 \mathrm{ft}$, J.C. Mellifs s.n. (B [20 0075274]); 1864, "Maximovicz" s.n. (LE); 1869, M. Vieillard 142 (B-2 sheets); 1884, [-15.9815 ; $\left.-5.7178^{\circ}\right]$, W. Ivest s.n. (B); 29/VIII/1903, Longwood s.n. (B-3 sheets [20 0075329, 20 0075330, and 20 0075331]); 30/VIII/1903, Longwood s.n. (B [20 0075332]); common at $\geq 1800 \mathrm{ft}, \mathrm{III} / 1956$, A.R. Ken 30 (K); Diana's Peak, s.d., L. Dalhousie s.n. (G-on 3 sheets); s.d. I. Buchanan 146 (B); s.d., Brehmer s.n. (B-2 sheets); s.d., Wellis s.n. (B-2 sheets [20 0075266 and 20 0075270], OXF); s.d., Perrotel s.n. (W); s.d., "Lefroy" s.n. (K [000214956]); s.d., Boos s.n. (W); s.d., Labscheid s.n. (W); s.d., Nuttal s.n. (K [000214955]); s.d., J.D. Hooker s.n. (K [000214960]); s.d., W. Robinson s.n. (K [000214964]); s.d., Anonymous, ex Herb. Forsyth. (K [000214958]); s.d., Anonymous (B [20 0075260]); s.d., Anonymous (B! [20 0075271-type of Ch. remota?]); s.d., Anonymous, ex Herb. Kew 883 (FI); s.d., Anonymous (K [000214961]); s.d., Anonymous (K [000214963]).

7. Hypolepis rugosula subsp. brownseyana Schwartsb. \& J. Prado. Type: [SAINT HELENA]. Ascension Island: [-7.9517; $-14.3474^{\circ}$ ], 1891?, Anonymous [unreadable] s.n. (holotype: K!-000650391). 
8. Hypolepis rugosula subsp. pichi-sermolliana Schwartsb. \& J. Prado. Type: DEMOCRATIC REPUBLIC OF THE CONGO: Dorsale ad ovest Del Lago Kivu, Montagne di Shamulamba, crinale a sud del rifugio del Groupe de Montagne de Kivu, elev., ca. 2600 m, 23/X/1953, R.E.G. Pichi-Sermolli 4441 (holotype: FI-PS!-on 2 sheets [19686]; isotypes: FI-PS! [19441], FI-PS! [19665]).

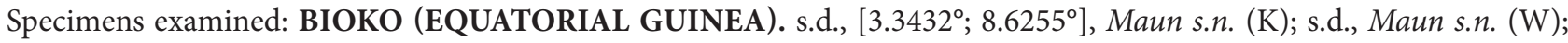
elev., $7000 \mathrm{ft}$, [3.5747 $\left.; 8.7620^{\circ}\right], 1860$, Maun 381 (K).

BELGIAN CONGO (DEMOCRATIC REPUBLIC OF THE CONGO). Kivu Nord, Virunga Westgruppe, $\left[-1.4310^{\circ}\right.$;

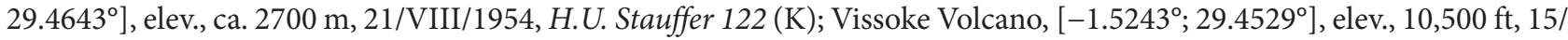
XII/1930, B.D. Burtt 3017 (K-on 2 sheets).

ETHIOPIA. Bale Mountains, above Rira, [6.7778 ${ }^{\circ} ; 39.7540^{\circ}$ ], elev., 3400 m, 08/II/1990, G. Miehe \& S. Miehe 2011 (K-on

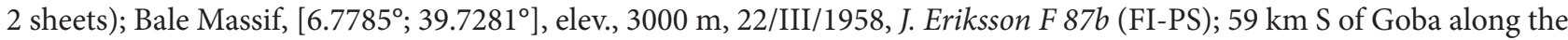

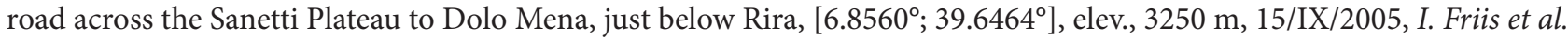
12074 (K-on 3 sheets).

UGANDA. Ruwenzori, [0.4120 ; 30.0142 ${ }^{\circ}$, elev., $9000 \mathrm{ft}, 04 / \mathrm{X} / 1905$, 'Baeor'(?) 569 (K); id., Bujuku Valley, near Bigo camp, $\left[0.3658^{\circ} ; 29.9442^{\circ}\right.$ ], elev., $3450 \mathrm{~m}, 02 / \mathrm{IV} / 1948$, O. Hedberg 646 (K); Western Province, Kigezi District, Virunga Ostgruppe, [-1.4503 $; 29.4218^{\circ}$ ], elev., ca. 3000 m, 14/XI/1954, H.U. Stauffer 783 (K).

KENYA. Murang'a, Nyandarua Districts, Kimakia forest station, $\left[-0.7453^{\circ} ; 36.7692^{\circ}\right]$, elev., 2475 m, 13/VII/1969, R.B. Faden \& A. Evans 69/897 (K-on 2 sheets); Embu District, above Castle Forest Station, [-0.3021 $\left.1^{\circ} 37.4097^{\circ}\right]$, elev., ca. 2350 m, 19/XII/1972, J.B. Gillett \& R.E. Holttum 20098 (K); id., Versante meridionale del Monte Kenya, $\left[-0.0480^{\circ} ; 37.2864^{\circ}\right]$, elev., 2700-3000 m, 13/XII/1966, R.E.G. Pichi-Sermolli 6892 (FI-PS); id., Versante meridionale del Monte Kenya, elev., 1800 m, 12/XII/1966, R.E.G. Pichi-Sermolli 6865 (FI-PS); Samburu District, Mt. Nyiru, [1.8230³ $37.0238^{\circ}$ ], elev., 7000 ft, $13 /$ XII/1972, J.B.C. Cameron 139 (K); Mount Kenia, elev., 10,000ft, 13/XII/1957, B. Verdcourt 2039 (K-on 2 sheets); id., 15/ XII/1957, B. Verdcourt 2063 (K-on 2 sheets, W); NE Elgon, [1.1881 ; 34.6244 ${ }^{\circ}$ ], elev., $9500 \mathrm{ft}, \mathrm{IV} / 1959$, Tweedie 1810 (K-on 3 sheets); Mount Elgon, Kitale, 27/XII/1960-01/I/1961, H. Löffler E-39(W); id., 27/XII/1960-01/I/1961, H. Löffler E-115 (W); North Nyeri District, Mt. Kenia, elev., 9500 ft, 06/IX/1963, B. Verdcourt 3727 (K); Western slopes of Mount Kenia, elev., ca. 3000 m, 28/IX-07/X/1909, E.A. Mearns 1698 (K); Nyeri District, Aberdare Mountains, Kiandongoro, $\left[-0.5348^{\circ} ; 36.7074^{\circ}\right]$, elev., 3020 m, 24/X/1971, R.B. Faden \& A.J. Faden 71/886 (FI-PS-on 2 sheets, K-on 2 sheets); Meru District, Volcanic cone Kirui, on the slopes of Ithanguni, $\left[-0.0768^{\circ} ; 37.5316^{\circ}\right.$ ] elev., ca. $2530 \mathrm{~m}, 28 / \mathrm{II} / 1970$, R.B. Faden \& A. Evans 70/116 (FI-PS, K-on 2 sheets); Narok District, Masailand, [ $\left.-0.8807^{\circ} ; 36.0429^{\circ}\right]$, elev., ca. $7100 \mathrm{ft}, 11 / \mathrm{VII} / 1961$, Glover et al. 2048 (FI-PS, K). TANZANIA. Kilimanjaro, Umbwe route, $\left[-2.9801^{\circ} ; 37.4241^{\circ}\right]$ elev., $2800 \mathrm{~m}, 16 / \mathrm{I} / 1997$, A. Hemp 1432 (K-on 2 sheets); id., above Nrwaa, [-3.2272 ${ }^{\circ}$; $37.4385^{\circ}$ ], elev., 2300 m, 03/III/1997, A. Hemp 1608 (K-on 2 sheets); Tanganjika, Kilimandscharo,

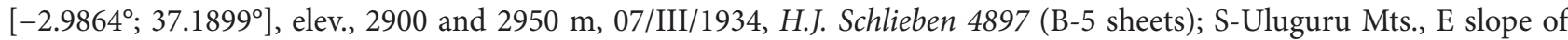

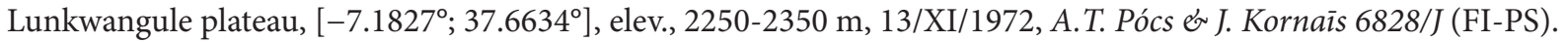

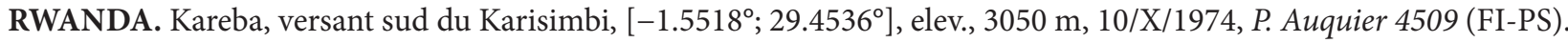

9. Hypolepis rugosula subsp. africana (C. Chr.) Schwartsb. \& J. Prado. Lectotype: MADAGASCAR. Süd-Betsiléo, Wald von Ankafina, [-18.3819 ; 48.0996º], III/1881, J.M. Hildebrandt 4139 (B! [20 0075279]; isolectotypes: B! [20 0075278], B! [20 0075283], BM!, LE!, LE! [ex Herb. Petropol.], P-n.v.-2 sheets, G! [ex Herb de Candolle], G!-on 2 sheets [ex Herb. Barbey-Boissier], W!).

? Phegopteris boryana Mett. Syntypes?: MAURITIUS. [-20.2906º ; 57.5870], 1846-1848, Boivin s.n. (W! [133/78-29], W! [133/78-30]); BOURBON. s.d., Bory s.n. (RB!-frag. [215817]).

Specimens examined: MADAGASCAR. Tanala, $\left[-20.9505^{\circ} ; 44.8154^{\circ}\right]$, s.d., L. Kitching s.n. (K!-syntype of H. rugosula var. africana); Pic d'Ivohibe, [-22.5122 $\left.{ }^{\circ} ; 46.9671^{\circ}\right]$, s.d., Humbert 3324 (BM!, C-n.v., P-n.v.-3 sheets-syntypes of Hypolepis rugosula var. africana).

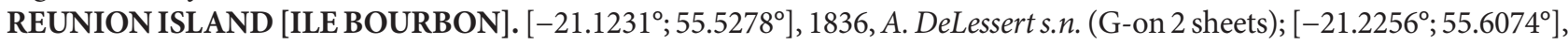
1853, Boivin B 813 (FI, G-2 sheets); s.d., Richard 494 (FI-W, LE); s.d., J. de Cordemoy 41 (K); s.d., L.J. Grey s.n. (K); s.d., I.B. Balfour s.n. (K); s.d., de Montbrisón s.n. (RB [13288]); Plaine des Fougéres, 1850, Anonymous (K [ex Herb. Mus. Paris]); s.d., Anonymous (OXF); s.d., Anonymous (K [ex Herb. Mus. Paris]).

10. Hypolepis rugosula subsp. rudis (Kunze) Schwartsb. Lectotype (designated here): PHILIPPINES. [Luzon]: in Philippinis, [Prov. Albay], [16.5394 ; 121.3921ํ], [1841], H. Cuming 140 (B! [20 0075269]; isolectotypes: B! [ex Herb. Koenpreuss], FI-W!, G! [ex Herb. Moricand], K! [000492488] K! [000 492495], LE! [ex Herb. Fischer], LE! [ex Herb. Petropol.], OXF!, RB!, W! [ex Herb. Mus. Wien], W! [ex Herb. Palat. Vindob]). 
Specimens examined: PHILIPPINES. Central Luzon: Prov. Bataam, Mt. Mariveles, Lamao R., $14^{\circ} 32^{\prime} \mathrm{N} ; 120^{\circ} 29^{\prime} \mathrm{E}$, elev., $350 \mathrm{ft}, 05 / \mathrm{XII} / 1903$, R.S. Williams 294 (K).

11. Hypolepis rugosula subsp. archboldii (Copel.) Schwartsb. Type: [NEW GUINEA]. [Dutch New Guinea, Mt. Wilhelmina, $7 \mathrm{~km}$ northeast of Wilhelmina-top, elev., $3560 \mathrm{~m}$, subalpine forest, common in ground moss, IX/1938], [-4.2185 ; $138.8669^{\circ}$ ], L.J. Brass \& E. Meyer-Drees 9852 (holotype: MICH-n.v;; isotypes: BM-n.v., FI-PS!, L! [0051755], UC [image!]).

12. Hypolepis rugosula (Labill.) J. Sm. subsp. rugosula. Lectotype: [TASMANIA]. Habitat in Capite Van-Diemen, [17911793], Labillardière s.n. (FI-W!-214897; isolectotypes: FI-W!-214898, FI-W!-214899, FI-W!-on 2 sheets [214903, 214904], FI-W!-216239, FI-W!-218473, G!-on 2 sheets [00048249, 00048250], G!-on 2 sheets [00048252, 00048253], G!-00048255, LE!-2 sheets; probable isolectotypes: B! [ex Herb. Mertens], G!-00048251, K!, L!- 908837-403, PRC!).

Cheilanthes amaurorachis Kunze. Lectotype: [TASMANIA]. Cultis Hortis Lipsiae ex Tasmania, s.d., Anonymous s.n. [G. Kunze?] (B! [20 0074521]; possible isolectotypes: BR!, K! [ex Herb. Hooker], K! [ex Herb. Kew]).

Hypolepis australis N.A. Wakef. Type: AUSTRALIA. Eastern Victoria: Arte River, [-37.5430 $148.7890^{\circ}$ ], 23/III/1941, N.A. Wakefield 107 (holotype: MEL-n.v. [1512588]).

Specimens examined: AUSTRALIA. Queensland: Brisbane, $\left[-27.4747^{\circ} ; 153.0218^{\circ}\right]$, s.d., A. Dietrich s.n. (LE p.p. [labeled “1" by Schwartsburd]); Lamington National Park, [-28.1926 $\left.{ }^{\circ} ; 153.1218^{\circ}\right]$, elev., ca. $1000 \mathrm{~m}, 13 / \mathrm{V} / 1977$, B.S. Parris \& J.P. Croxal 6235 (K). New South Wales: The Gulf Creek, sunny corner, 15 miles east-north-east of Bathurst, [ $\left.-33.3745^{\circ} ; 149.6600^{\circ}\right], 03 /$ III/1964, E.F. Constable 4759 (K); Mt. Spirabo, 20 miles SSE of Tenterfield, [-29.2670 ${ }^{\circ}$ 152.1081 ${ }^{\circ}$, elev., $1440 \mathrm{~m}, 07 / \mathrm{V} / 1961$, E.F. Constable NSW P8321 (K-on 5 sheets); The Wines, south of Sassafras, [ $\left.-35.0509^{\circ} ; 150.2612^{\circ}\right], 19 / \mathrm{X} / 1957$, E.F. Constable NSW P7957 (K); below Govetts Leap, Blackheath, 33³8’'S; 150¹9’E, elev., 660 m, 15/III/1977, R. Coveny \& S.K. Roy 9190 (K, WELT). Australian Capital Territory: New Chum Road, Cotter Valley, [-35.6088 ; 148.8236 $]$, 30/III/1964, M. Gray

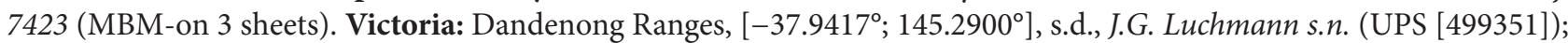
Peninsula Country Golf Club, near Franstone, $40 \mathrm{~km}$ south-south-west of Melbourne, 38 $08^{\circ} \mathrm{S} ; 145^{\circ} 11^{\prime} \mathrm{W}, 07 / \mathrm{X} / 1973$, R.J. Chinnock P781 (K-on 3 sheets); East Gippsland, [-38.3680'; 146.6118º], 10/II/1973, A.C. "Beanglehole" 41430 (K); Dematis Gully, 11/V/1953, R. Melville \& J. Willis 3842 (K). Unknown locality: s.d., F. von Mueller s.n. (BR); Jenolan Caves, X/1899, W.F. Blakely s.n. (FI).

KANGAROO ISLAND [AUSTRALIA, South Australia]. ca. 4 km east of Cape Borda, [ $-35.8109^{\circ} ; 137.1885^{\circ}$ ], 29/XII/1957, R. Schodde 528 (K-on 2 sheets).

KING'S ISLAND [TASMANIA, King's Island]. 1802-1805, [-39.8581; $\left.143.9852^{\circ}\right]$, R. Brown 16a (K, LE).

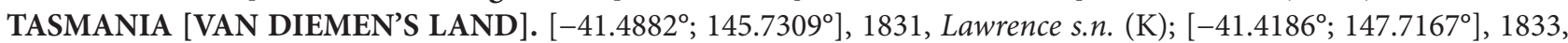
R.C. Gunn s.n. (BR); s.d., R.C. Gunn s.n. (FI, LE-2 sheets); 31/VIII/1840, J.D. Hooker 1275 (K); 1843, S.G. Hannaford s.n. (G-on 2 sheets); Valley Mount Wellington, [-42.8958 $\left.{ }^{\circ} 147.2652^{\circ}\right], 1820$ ?, A. Wossman s.n. (FI-W [214907]); Gordon River

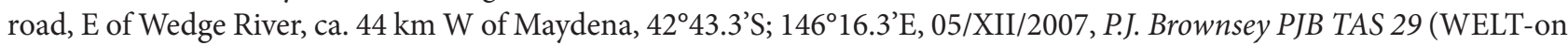
2 sheets); s.d., W. Archer s.n. (LE); 1861?, Anonymous (OXF); s.d., Anonymous (W).

13. Hypolepis rugosula subsp. lactea (Bronswey \& Chinnock) Schwartsb. Type: NEW ZEALAND. Wellington: Eastbourne, Butterfly Creek, around fallen log, disturbed ground on creek bank, in beech forest, [41 $\left.{ }^{\circ} 18^{\prime} \mathrm{S} ; 174^{\circ} 54^{\prime} \mathrm{E}\right], 21 / \mathrm{II} / 1979$, P.J. Brownsey NZ 1356 (holotype: WELT! [P11516a]; isotype: CHR-n.v.).

Specimens examined: NEW ZEALAND, NORTH ISLAND. South Auckland, Kauaeranga Valley, $\left[-36.9520^{\circ} ; 174.4936^{\circ}\right]$, elev., 500 ft, 30/I/1971, J.P. Croxall \& B.S. Parris 1479 (K-on 2 sheets); Rodney County, Kaipara Hills, 36 $25^{\circ}$ 'S; $174^{\circ} 30^{\prime}$ E, elev., 140 m, 04/I/1987, M.E. Young s.n. (WELT-on 3 sheets [P 17888 a-c]); Wellington, Mt. Kaukau, $\left[-41.2343^{\circ} ; 174.7805^{\circ}\right.$ ], elev., 1500 ft, VIII/1971, R.J. Chinnock \& B.S. Parris 3172 (K-on 2 sheets); Wellington Prov., east of Masterton, Stronvar, Te Haroto Station, $41^{\circ} 04^{\prime}$ S; $175^{\circ} 56^{\prime} \mathrm{E}$, elev., 300 m, 12/III/2008, P.J. Bronwsey s.n. (WELT [P 022219]); Wellington Prov., east of Masterton, Stronvar, Te Haroto Station, $41^{\circ} 04.3^{\prime} S$; $175^{\circ} 56.3^{\prime} \mathrm{E}$, elev., $300 \mathrm{~m}, 12 / \mathrm{III} / 2008$, B. Sneddon \& L. Perri s.n. (WELT [P 022218]).

NEW ZEALAND, [WAIKATO], MIDDLE ISLAND. [-36.9574; $\left.176.0804^{\circ}\right]$, s.d., Strange s.n. (LE p.p.).

NEW ZEALAND, SOUTH ISLAND. Greymouth, $\left[-42.4612^{\circ} ; 171.2266^{\circ}\right], 1875-1885$, R. Helms, N.Z.E. 49 p.p. (L-384114);

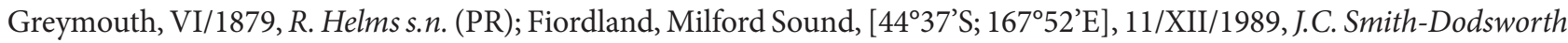
s.n. (WELT-on 2 sheets [P 18047a and P 18047b]).

NEW ZEALAND. Unknown locality: 1843-1844, W. Stephenson 21 (G-2 sheets, K, W); Port Nicholson, V/1849, D. Lyale s.n. (K); s.d., Knight s.n. (RB [215825 A]). 
14. Hypolepis rugosula subsp. rufobarbata (Colenso) Schwartsb. Lectotype: NEW ZEALAND. Waipawa County, between Norsewood and Danneverke, hills, skirts woods, [-39.9000 $\left.; 176.5892^{\circ}\right], 1882$, W. Colenso s.n. (WELT! [P3346]; isolectotype: $\mathrm{K} !)$.

Polypodium viscidum Colenso. Lectotype: NEW ZEALAND. open spots, mountains, near Waikare Lake, [-37.4299 175.2652], XII/1841, W. Colenso s.n. (WELT-n.v. [P3189]; probable isolectotype: K! [“Colenso 269”]).

Specimens examined: NEW ZEALAND, NORTH ISLAND. Auckland, 1859, F. Hochstetter 36 (W-2 sheets); Auckland, Spragg's Bush, Waitakere Ranges, [-36.8652 ${ }^{\circ}$; 174.5178 ${ }^{\circ}$, 19/IX/1970, B.S. Parris 853 (K); South Auckland, Mt. Pirongia, 23/IV/1966, J.J. Bedford s.n., Exsic. Parris 514 (K-on 2 sheets); South Auckland, Kaitarakihi track from Kopu-Hikuai road, [-37.0384 ; $175.2042^{\circ}$ ], elev., $2000 \mathrm{ft}, 31 / \mathrm{I} / 1971$, B.S. Parris \& J.P. Croxall 1480 (K); South Aukland, Mt. Te Aroha, [-37.5346 ; $175.7430^{\circ}$ ], elev., $2700 \mathrm{ft}, 09 / \mathrm{I} / 1971$, B.S. Parris \& J.P. Croxall 1453 (K); Taxod forest at Ohakune, Tongariro National Park,

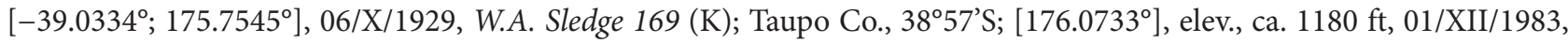
R.O. Gardner 4009 (K); Te Aroha, Tawa-Rata forest, elev., 1600 ft, 15/I/1966, B.S. Parris 334 (K); Kaukau, Howraki Gulf, $\left[-41.2294^{\circ} ; 174.7826^{\circ}\right]$, XII/1848, Lyell s.n. (K-2 sheets); Taranaki, Mt. Egmont National Park, $\left[-39.2963^{\circ} ; 174.0640^{\circ}\right]$, elev., 2800 m, 15/IV/1966, B.S. Parris 475 (K); Taranaki, Mt. Egmont, Stratford road, 26/X/1970, B.S. Parris 1024 (K); Kaitoke Waterworks, Upper Hut, [-41.1382 $; 175.1525^{\circ}$ ], 20/II/1979, P.J. Brownsey NZ 1359 (WELT-on 2 sheets); (from) Murgaroa Swamp, Upper Hut, (cultivated at Orari Gardens, Wellington), 20/XII/1979, P.J. Brownsey NZ 1435 (WELT); Wellington, Mt. Kaukau, elev., 1500 ft, VIII/1971, R.J. Chinnock \& B.S. Parris 3173 (K); Wellington, Pihanga Saddle, 15/VIII/1970, J.P. Croxall \& B.S. Parris 769 (K); Wellington, Akatarawa Saddle, [-40.9905'; $\left.175.1417^{\circ}\right]$, elev., $1400 \mathrm{ft}, 23 / \mathrm{X} / 1970$, B.S. Parris 954 (K); Grey Co., North of Barrytown, 42 $12^{\prime}$ S; [171.4622 ${ }^{\circ}$, R.O. Gardner 4492 (K).

NEW ZEALAND, [WAIKATO], MIDDLE ISLAND. [-36.9563; $176.0850^{\circ}$ ], s.d., Strange s.n. (LE p.p.).

NEW ZEALAND, SOUTH ISLAND. Westland, Valley of the Teremakau, $\left[-43.4443^{\circ} ; 170.0981^{\circ}\right], 1889$, T.B. Cartwright s.n. (OXF); Westland, foresta all'inizio del sentiero per il Fox Glacier dove si abbandona la strada, versante destro de la valle, $\left[-43.4763^{\circ} ; 170.0435^{\circ}\right], 10 / X I / 1956$, R.E.G. Pichi-Sermolli 6276 (FI-PS); Canterbury, sulle rive del torrente dell'Ashley Gorge nella foresta di Nothofagus cliffortioides, [-43.5651 ${ }^{\circ}$; $170.8556^{\circ}$ ], 10/XI/1956, R.E.G. Pichi-Sermolli 6192 (FI-PS); Greymouth, $\left[-42.6642^{\circ} ; 171.4964^{\circ}\right]$, VIII/1878, R. Helms s.n. (G); Greymouth, s.d., R. Helms s.n. (PRC); Greymouth, 1875-1885, $R$. Helms, N.Z.E. 49 p.p. (L-384113); Otira, Westland, Barrack Creek banks, [-42.8316 ; $\left.171.5804^{\circ}\right]$, elev., $1700 \mathrm{ft}$, N. Lothian s.n. (K); Canterbury, Banks Peninsula, Kaituna Valley below Herbert Peak, 28/XII/1961, R. Melville 5775 (K-on 2 sheets); Dunedin, $\left[-45.7766^{\circ} ; 170.4040^{\circ}\right]$, I-IV/1875, M. Filhol s.n. (LE).

NEW ZEALAND, STEWART ISLAND. [-46.8836 ; $\left.167.9295^{\circ}\right], \mathrm{II} / 1910$, B. Leland et al. 317 (G, K).

NEW ZEALAND. Unknown locality: [Middle Island?], 1850?, Strange s.n. (G-on 2 sheets); 1875, W. Walker s.n. (FI); 1881, W. Colenso s.n. (K); s.d., W.T.L. Travers s.n. (LE p.p.); s.d., Knight s.n. (RB [215825 B]).

15. Hypolepis rugosula subsp. subantarctica (Bronswey \& Chinnock) Schwartsb. Type: [NEW ZEALAND, CAMPBELL ISLAND]. Cultivated at CHR (G 11407) from Campbell Island, ex D.R. Given s.n., 26/III/1981, P.J. Brownsey s.n. (holotype: WELT!-on 2 sheets [P11518/A and P11518/B]; isotypes: AK-n.v., CHR-n.v.).

Specimens examined: NEW ZEALAND, CAMPBELL ISLAND. Above Smoothwater Bay, $\left[-52.5409^{\circ} ; 169.1804^{\circ}\right], 23 /$ III/1947, W.B. Brockie s.n. (WELT [P 7786]). 